\title{
Regulatory Role of Mesenchymal Stem Cells on Secondary Inflammation in Spinal Cord Injury
}

\author{
Qi-Ming Pang ${ }^{1,2}$, Si-Yu Chen (D)', Sheng-Ping Fu',2, Hui Zhou ${ }^{3}$, Qian Zhang ${ }^{4}$, Jun Ao², Xiao-Ping Luo', \\ Tao Zhang ${ }^{1,2}$
}

'Key Laboratory of Cell Engineering of Guizhou Province and Regenerative Medicine Centre, Affiliated Hospital of Zunyi Medical University, Zunyi, People's Republic of China; ${ }^{2}$ Department of Orthopedics, Affiliated Hospital of Zunyi Medical University, Zunyi, People's Republic of China; ${ }^{3}$ The First School of Clinical Medicine, Zunyi Medical University, Zunyi, People's Republic of China; ${ }^{4}$ Department of Human Anatomy, Zunyi Medical University, Zunyi, People's Republic of China

Correspondence: Tao Zhang; Qian Zhang, Email oceanzt@I63.com; zmczq@I63.com

\begin{abstract}
Spinal cord injury (SCI) is a catastrophic condition with high morbidity and mortality that still lacks effective therapeutic strategies. It is well known that the most important stage in SCI pathogenesis is secondary injury, and among the involved mechanisms, the inflammatory cascade is the main contributor and directly influences neurological function recovery. In recent years, increasing evidence has shown that mesenchymal stem cells (MSCs) transplantation is a promising immunomodulatory strategy. Transplanted MSCs can regulate macrophage-, astrocyte-, and T lymphocyte-mediated neuroinflammation and help create a microenvironment that facilitates tissue repair and regeneration. This review focuses on the effects of different types of immune cells and MSCs, specifically the immunoregulatory capacity of MSCs in SCI and repair. We will also discuss how to exploit MSCs transplantation to regulate immune cells and develop novel therapeutic strategies for SCI.
\end{abstract}

Keywords: spinal cord injury, mesenchymal stem cells, immune cells, neuroinflammation, immunoregulation, macrophage, astrocyte, T cell

\section{Introduction}

Spinal cord injury (SCI) is a potentially devastating event in the central nervous system (CNS) that can lead to the loss of sensory and motor functions below the damaged segment with huge burdens on patients, their families, and society due to the high treatment cost. ${ }^{1,2}$ The global rate of traumatic SCI ranges from 250,000 to 500,000 people annually and will gradually climb with the growing number of people using modern transportation along with aging populations. ${ }^{3,4} \mathrm{SCI}$ triggers a sequential set of pathophysiological processes that can be classified as primary and secondary injury. ${ }^{5}$ Acute primary injury commonly occurs due to the mechanical insult, which can be caused by laceration, contusion, compression, or transection. ${ }^{6,7}$ These events severely disrupt neuronal pathways and axonal networks, cause hemorrhage, and compromise the blood-spinal cord barrier (BSCB) ${ }^{8,9}$ It is widely believed that the most important phase is secondary injury, which develops a few minutes after the initial injury. It consists of a series of auto-destructive cellular and molecular changes, such as inflammatory response, glial scar formation, edema, thrombosis, free radical release, and apoptotic and necrotic cells death. ${ }^{10,11}$ Among the mechanisms of secondary injury, a robust and chronic inflammatory response has been observed at the injury epicenter and in surrounding areas. ${ }^{12,13}$ Studies have demonstrated that this response can contribute to a wide range of inflammatory and autoimmune disorders that exacerbate lesion progression and hamper neurological function recovery. ${ }^{13,14}$ Unfortunately, there is still a lack of therapeutic methods targeting neuroinflammation; only methylprednisolone has shown efficacy and was approved by the US Food and Drug Administration for clinical treatment. ${ }^{15,16}$ However, its use has gradually declined over the past few decades due to the serious complications related to glucocorticoid therapy, such as gastrointestinal bleeding, wound infection, pulmonary embolism, and sepsis. ${ }^{17,18}$ Despite the controversies concerning the glucocorticoid treatment, its effects suggest that suppressing the inflammatory response after injury is a viable approach to improve the condition of SCI patients. ${ }^{19,20}$ It is 
therefore imperative to investigate the roles of different types of immune cells on excessive neuroinflammation in order to develop new therapeutic strategies targeting neuroinflammation in the setting of SCI.

Over the past few decades, stem cell-based therapy has provided new hope for treating SCI patients. ${ }^{20}$ Mesenchymal stem cells (MSCs) have attracted increasing attention due to their remarkable advantages of self-renewal, differentiation potential, and immunoregulation. ${ }^{21}$ The International Society for Cellular Therapy sets a minimum standard of MSCs as follows: cells that are positive for the surface markers of cluster of differentiation (CD)73, CD90, CD29, and CD105, but not with CD14, CD45, CD34, CD11b, or human leukocyte antigen-DR; are plastic-adherent and fibroblast-like under standard culture conditions; and can differentiate into chondrocytes, adipocytes and osteoblasts in vitro. ${ }^{22}$ Due to the low expression of costimulatory molecules and class II major histocompatibility complex, these pluripotent stem cells do not trigger an obvious immune response after transplantation. ${ }^{22,23}$ To date, MSCs have been isolated from distinct adult tissues (eg, bone marrow, peripheral blood, adipose tissue) and neonatal tissues (eg, umbilical cord and placenta). ${ }^{24,25}$ MSCs from different sources have been demonstrated to be effective in animal models of numerous inflammatory diseases as well as in ongoing clinical trials including SCI. ${ }^{26-29}$ Growing evidence suggests that these multipotent cells can induce an immunosuppressive and reparative microenvironment through cell-cell interaction and a paracrine effect, thereby promoting anatomical and functional recovery after SCI. ${ }^{30,31}$

In this review, we summarize the roles of immune cells and transplanted MSCs with a focus on the immunomodulatory effects of MSCs in SCI and repair. We will pay special attention to the fact that preconditioning may further promote the effects of MSC-based therapy in SCI models. Adequately clarifying the contributions of different immune cells, MSCs, and their reciprocal interactions to SCI pathogenesis and repair will be of great value for developing new therapeutic approaches for SCI.

\section{Inflammation After SCI}

Although microglia can be found throughout the CNS and numerous immune cells are found in the meningeal spaces, the absence of peripheral immune cells in the normal CNS implies that the spinal cord is privileged from normal immune surveillance. $^{32}$ The BSCB consists of three main cellular components: capillary basement membrane, astrocytes, and pericytes. ${ }^{33}$ Similar to the blood-brain barrier, the BSCB is essential for excluding peripheral immune cells and various inflammatory and toxic metabolic products from the CNS, thereby maintaining microenvironment stability. ${ }^{34,35}$ Following SCI, cells damaged at the injury site can produce types of intracellular proteins and cell debris known as damage-associated molecular patterns (DAMPs) that act as strong inflammatory stimuli and are responsible for the excessive inflammatory response post-SCI. ${ }^{36,37}$ DAMPs bind to pattern recognition receptors in resident inflammatory cells, including resident microglia and astrocytes, resulting in the rapid activation of these cells. ${ }^{37,38}$ In response to neuropathology, astrocytes undergo a suite of molecular, morphological, and functional remodeling, which eventually leads to the acquisition of new functions. ${ }^{39}$ However, the abilities of astrocyte proliferation and polarization vary with the intensity and type of stimulation after SCI. With the increasing stimulation intensity, cell hyperplasia, proliferation, migration, and alignment occur gradually, and these reactive astrocytes show a gradual up-regulation of glial fibrillary acidic protein (GFAP) and secretion of cytokines (eg, interleukin (IL)-6, transforming growth factor beta (TGF- $\beta$ ), IL-1 $\beta$ ) and other molecules (eg, cyclooxygenase (COX)-2, inducible nitric oxide synthase, S100 $\beta$ ). ${ }^{39}$ When the BSCB is damaged, these inflammatory mediators can drive peripheral immune cells to the lesion site; they then polarize towards pro-inflammatory phenotypes and exhibit cytokine expression patterns similar to the resident inflammatory cells, resulting in a more severe local inflammatory response that consequently hinders neurological function recovery (Figure 1). ${ }^{40,41}$ A sequential inflammatory cascade is switched on following SCI. Neutrophils are driven to the lesion site within 24 hours and facilitate phagocytosis and the removal of cellular debris; many neutrophils also secrete distinct oxidative and tissue-degrading enzymes, proteases, reactive oxygen species (ROS), and tumor necrosis factor (TNF)- $\alpha$, creating a harmful microenvironment that is neurotoxicity to neurons. ${ }^{14,42,43}$ After neutrophil infiltration, blood-derived monocytes are the next inflammatory cells to appear at the lesion site at approximately 2 days and peaking on 5-7 days. $^{44,45}$ These cells play critical roles in clearing cellular debris, promoting angiogenesis, and modulating cytokine secretion and the activation and proliferation of $\mathrm{T}$ lymphocytes. ${ }^{46}$ Lymphocyte numbers are highest at 9 days and are essential for the progression or resolution of secondary damage by adopting distinct immunophenotypes. ${ }^{47}$ The three 


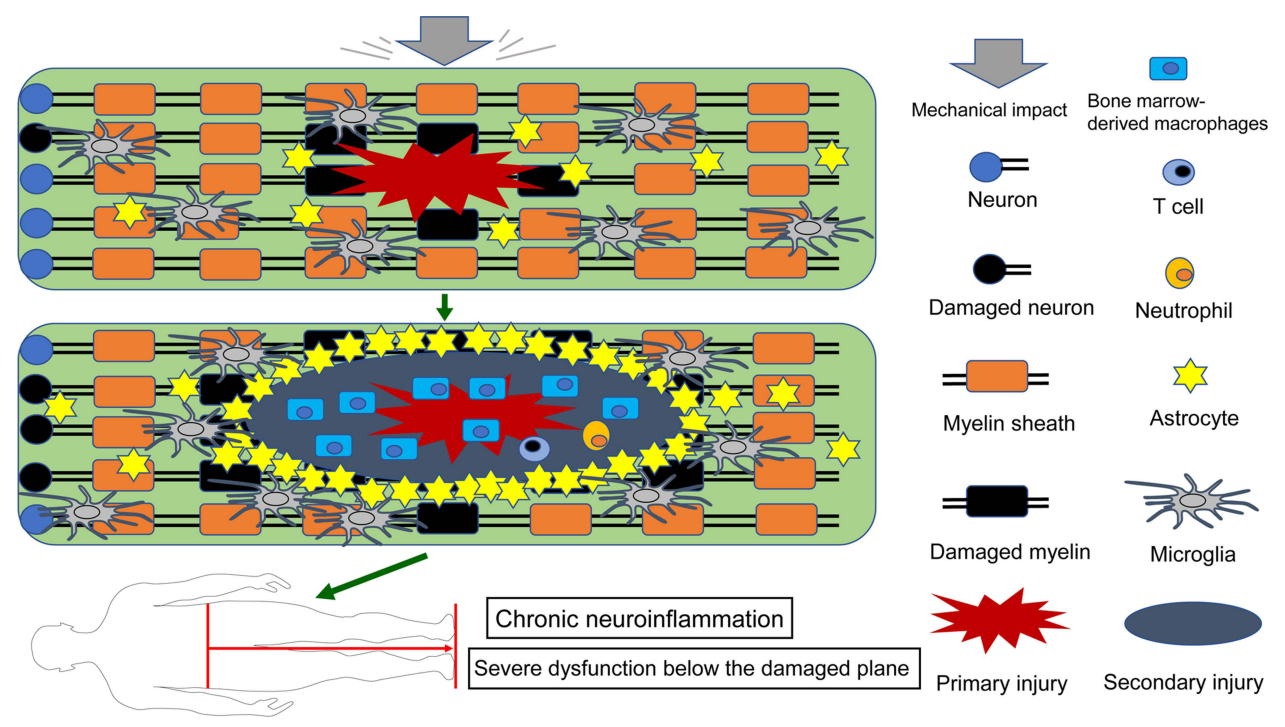

Figure I Schematic depicting the activation and migration of resident and peripheral immune cells following SCl. After primary injury, resident astrocytes, microglia, and other glial cells are immediately activated and migrate to the injury site (top). Subsequently, peripheral inflammatory cells including neutrophils, bone marrow-derived macrophages, and lymphocytes infiltrate into the epicenter of the injured spinal cord, and these activated immune cells can exacerbate damage, causing a wider range of secondary injury. Glial cells (mainly astrocytes) form glial scar to seclude the damaged area, and microglia are mainly present around the injury site (middle). These persistent pathophysiological changes ultimately result in severe dysfunction below the damaged segment (bottom).

main types of immune cells together with their secretion of various neurotoxic factors including inflammatory mediators, free radicals, matrix metalloproteinases, proteolytic enzymes, ROS, and apoptosis-inducing molecules extend the primary damage to adjacent normal tissues, causing further apoptosis and necrosis of neurons and glial cells. ${ }^{48,49}$

During the course of skin and muscle wound healing, there is generally a distinct shift in the inflammatory response. Initially, various pro-inflammatory cells such as M1 macrophages and neutrophils predominate the lesion site. ${ }^{50}$ They play critical roles in removing cell debris and providing a sterile microenvironment for tissue regeneration. ${ }^{51}$ Following beneficial and transient inflammation, an anti-inflammatory and reparative phase is induced that is mainly regulated by regulatory T cells (Treg) and M2 macrophages, which can promote angiogenesis and extracellular matrix deposition. ${ }^{52,53}$ However, unlike the cutaneous and muscular healing processes, there is no corresponding anti-inflammatory and remodeling phase after $\mathrm{SCI} .{ }^{54}$ Pro-inflammatory cells persist at the lesion site, resulting in secondary neuronal and glial degeneration, which further exacerbates neurological dysfunction. ${ }^{55}$ Effective strategies to induce the anti-inflammatory remodeling phase after the acute inflammatory response are extremely important for promoting neurological recovery post-SCI.

\section{Contribution of Distinct Immune Cells to SCI Inflammation}

The inflammatory response plays critical roles in all the mechanisms of secondary injury and directly influences the neurological outcome post-injury. ${ }^{56}$ Neuroinflammation was previously regarded as an adverse consequence after SCI because it led to a broader range of destructive processes including widespread healthy spinal cord tissue damage and further neuronal degeneration. With substantial advances in the understanding of SCI pathophysiology, it was gradually revealed that the early inflammatory response could also generate a permissive microenvironment for the regeneration of damaged neurons and axons, similar to early inflammatory benefits in other tissues. ${ }^{57-59}$ Neuroinflammation is composed of multifaceted cellular and molecular responses, and the unique effects of immune cells including macrophages, astrocytes, and lymphocytes are essential for the occurrence and progression of inflammatory responses post-SCI. ${ }^{60}$

\section{Effect of Macrophages on Neuroinflammation}

The phase-specific functions of macrophages - ranging from initial neuroinflammation to eventual tissue remodeling and repair-are essential for functional locomotion recovery. ${ }^{55}$ These cells primarily originate from resident microglia that 
are activated minutes to hours after SCI, but after 2 days they are mainly from circulating monocytes. ${ }^{61}$ These monocyteand microglia-derived macrophages are still hard to distinguish owing to their similar phenotypes and morphologies. ${ }^{60,62}$ Based on their phenotypic and functional differences, macrophages can be divided into two main subtypes termed M1 and M2. ${ }^{63}$ T-helper 1 (Th-1) cytokines such as TNF- $\alpha$ and interferon gamma (IFN- $\gamma$ ) induce the polarization of classically activated M1 macrophages characterized by up-regulation of inflammatory cytokines such as IL-23, IL-1 3 , TNF- $\alpha$, and IL-12. ${ }^{64,65}$ These mediators can kill neurons, induce axonal degeneration, and further contribute to the activation of neurotoxic Th1 and Th17 cells. ${ }^{66,67}$ In contrast, alternatively activated M2 macrophages are the product of exposure to Th2-associated cytokines such as IL-4 and IL-13. ${ }^{68,69}$ These cells are able to produce high levels of antiinflammatory cytokines such as IL-10, IL-4, and TGF- $\beta$, which are essential for inhibiting excessive inflammatory responses and promoting wound remodeling and repair. ${ }^{69,70}$ In rat models of SCI, M2 macrophages can be observed early, but dissipate rapidly within 3-7 days after injury, while M1 macrophages remain in the lesion indefinitely. ${ }^{31,71}$ In SCI patients, by $\sim 5$ days post-injury, activated macrophages are abundant in the spinal cord for up to a year, and these cells could produce potentially destructive oxidative and proteolytic enzymes. ${ }^{45}$

\section{Effect of Astrocytes on Neuroinflammation}

It was previously believed that macrophages were the only cell type involved in neuroinflammation. However, it is now known that astrocytes are able to modulate innate and adaptive immune responses in the CNS by activating diverse pathways. ${ }^{38,72,73}$ For example, as a critical modulator for neuroinflammation, nuclear factor (NF)- $\mathrm{KB}$ signaling is highly activated by its associated gene expression after SCI, suggesting that this pathway is important in the pathophysiological process of CNS injury. ${ }^{74-76}$ In a mice model of SCI, inhibiting astroglia NF- $\mathrm{kB}$ was demonstrated to down-regulate monocyte chemoattractant protein (MCP)-1 expression, inhibit leukocyte recruitment, and promote axonal regeneration and germination, finally facilitating functional locomotion recovery. ${ }^{77-79}$ Furthermore, inhibiting the activation of astrocytes after SCI has been shown to attenuate inflammation and promote axonal regeneration and motor recovery. ${ }^{80}$ Paradoxically, Anderson et $\mathrm{al}^{81}$ demonstrated that attenuating scar-forming astrocytes elicited a more severe inflammatory response and prevented axonal regeneration in the CNS, leading to more severe dysfunction. These diverse outcomes are likely to be explained by the induction of an astrocyte reaction that is both phenotypically and functionally heterogeneous. Similar to the situation of M1 and M2 macrophages, study has revealed that astrocytes have more than one type of polarization. ${ }^{44}$ Inflammation and ischemia induce the pro-inflammatory A1 and anti-inflammatory A2 phenotypes. ${ }^{82}$ It should be noted that the current nomenclature oversimplifies the astrocyte activation continuum, implying that reactive astrocytes have more than two polarization types. The naming convention of A1/A2 is intended to promote scientific research and academic exchanges. ${ }^{83,84} \mathrm{~A} 1$ astrocytes strongly increase the expression of the classical complement cascade genes including complement component1s $(\mathrm{C} 1 \mathrm{~s}), \mathrm{C} 1 \mathrm{r}, \mathrm{C} 3$, and $\mathrm{C} 4$, which were previously shown to be harmful to synapses, indicating that A1 astrocytes might be the "bad" player in neurological repair and remodeling. ${ }^{85,86}$ In contrast, A2 astrocytes up-regulate the expression of neurotrophic factors and cytokines such as leukemia inhibitory factor, cardiotrophin-like cytokine factor 1, IL-10, and IL-6 to support neuronal restoration and survival, as well as synaptic repair, suggesting that A2 astrocytes might be the "good" players in neuroinflammation. ${ }^{87-89}$ Therefore, differentiation of astrocytes into an A2 phenotype may facilitate functional recovery after SCI while inhibiting secondary inflammation-mediated damage. These researches have emphasized the phenotypic and functional heterogeneity of reactive astrocytes. However, current studies mainly focus on the rodent astrocytes that have been shown to be significantly different from human astrocytes in morphology, activation timing, and gene expression. ${ }^{90}$ Hence, it is unclear whether the gene expression and regulation of reactive astrocyte subtypes observed in rodents are directly applicable to human tissues. ${ }^{90}$ But researchers can explore more extensively by selecting suitable model species, such as non-human primates, whose astrocytes have a transcription profile similar to that of human astrocytes.

\section{Effect of T Lymphocytes on Neuroinflammation}

$\mathrm{T}$ lymphocytes play important roles in the pathogenesis of neuroinflammation following CNS injury. ${ }^{91}$ As a key modulator of the adaptive immune response, CD4+ T cells mainly differentiate into four subtypes-Th1, Th2, Th17, and Treg cells - that are essential for affecting the outcome of inflammatory response by restricting or activating other 
immune cell responses. ${ }^{92,93}$ Each CD4+ T cell subtype has a specific transcriptional program and cytokine expression pattern that can aggravate or mitigate the degree of secondary injury. ${ }^{94} \mathrm{CNS}$ injury recovery is likely to depend on the balance among these subtypes. ${ }^{95}$ Th1 cells are the product of exposure to IFN- $\gamma$ and IL-12 and can induce activation of the Th1-associated specific transcription factor, T-bet, which feeds back to stimulate the expression of additional IFN- $\gamma$, IL-12, and TNF- $\beta$, thereby promoting macrophage-dependent neuroinflammation and cell-mediated immunity. ${ }^{66,96,97}$ T-bet-mediated cytokines are also able to induce Th2 phenotype repolarization toward Th1. ${ }^{98}$ Hence, Th1 might play destructive roles in CNS injury and repair. The key cytokine required for Th2 differentiation is IL-4, which contributes to the expression of the master regulator transcription factor GATA3 of Th2, and itself is released by Th2 in addition to IL13 and IL-10. ${ }^{99,100}$ Known effector functions of Th2 include promoting eosinophil accumulation and inducing B cells to produce immunoglobulin (Ig)E and IgG1, as well as inhibiting M1 macrophage activation. ${ }^{66}$ Some studies have demonstrated that shifting CD4+ T cells to Th2 by potent Th2 inducers like glatiramer acetate can improve the outcome of CNS injury. ${ }^{101}$ As such, Th2 cells have a greatly protective role. Apart from Th1 and Th2 cells involved in the neuroinflammation, study has shown that both Th17 cells and Treg are essential to regulate the immune response postSCI. ${ }^{91}$ Th17 cells are defined by the characteristic production of IL-17A, IL-17F, IL-21, and IL-22 along with the expression of the master transcription factor ROR $\gamma \mathrm{t} .{ }^{102} \mathrm{Th} 17$ cells are pro-inflammatory and essential to protect against pathogens by recruitment of neutrophil granulocytes. ${ }^{103}$ This cell type plays a determinant role in various inflammatory diseases, including multiple sclerosis, ankylosing spondylitis, inflammatory bowel disease, and rheumatoid arthritis, as well as SCI. ${ }^{104,105}$ In contrast, Treg are characterized by the specific transcription factor Foxp3 and play a significant role in inhibiting immune response-related neuroinflammation by secreting anti-inflammatory cytokines such as TGF- $\beta$ and IL-10. ${ }^{106,107} \mathrm{Th} 1$ and Th17 cells are considered to be the main drivers of pathogenesis because they predominate at the lesion site where they further induce an inflammatory response by activating macrophages and neutrocytes. ${ }^{108}$ Accumulating data suggest that correcting the imbalance of Th1/Th2 and Th17/Treg cells could improve the prognosis of SCI.

\section{Contribution of MSCs Transplantation to SCI Prognosis}

A premise of effective MSC-based therapy is that MSCs migrate from their sources via the bloodstream and home to the injured site. ${ }^{118,119}$ Researchers have revealed that MSCs are attracted to the area of damage by various diverse chemokines, such as platelet-derived growth factor-AB, stromal-derived factor-1, and macrophage-derived chemokine. ${ }^{120}$ Study has uncovered that MSCs express a large amount of CXCR4, which is essential for their homing and migrating. ${ }^{121}$ However, natural migration into lesion sites is extremely limited. ${ }^{122}$ A similar situation is observed to be found when MSCs are systemically administered because they are trapped in vascularized tissues, especially the lungs. ${ }^{119}$ Therefore, an effective and simple MSCs transplantation method is local injection into the damaged area or surrounding healthy tissue. ${ }^{123}$ Initial attention mainly focused on the differentiation potential of MSCs because they might differentiate into neurons and glial cells to replace the dead cells and reconstruct the integrity of neuronal conductive pathways; however, there remains a lack of related differentiation evidence. ${ }^{112,117}$ Interestingly, MSCs engraftment can still improve various functional parameters in animal models of $\mathrm{SCI}^{124}$ (Table 1). Scientists proposed that these results might be largely explained by their paracrine effects or direct interactions with immune cells. ${ }^{125}$

Angiogenesis is particularly important for the recovery of neurological function, so it is a valuable research direction for wound healing processes. ${ }^{33}$ Studies have shown that MSCs significantly promote angiogenesis by secreting a series of factors, including vascular endothelial growth factor, platelet-derived growth factor, TGF- $\beta$, and IL- 6 , which promote BSCB repair and neurogenesis after SCI. ${ }^{126-128}$ Meanwhile, an increasing body of evidence shows that MSCs transplanted into SCI models release many neurotrophic factors such as glial cell-derived neurotrophic factor, BDNF, neurotrophin-3, and basic fibroblast growth factor; the production of these soluble factors contributes to the inhibition of cell apoptosis and necrosis and regeneration of axons and myelin sheaths. ${ }^{129-131}$ Apart from these reparative properties, MSCs also have robust anti-inflammatory roles. ${ }^{130,132}$ For example, bone marrow-derived mesenchymal stem cells (BM-MSCs) transplanted into a rat model of SCI can reduce the infiltration of neutrophil and significantly down-regulate the expression of pro-inflammatory cytokines. ${ }^{133}$ In addition to neutrophil, MSCs can also skew the balance of inflammatory cytokines in an anti-inflammatory direction by modulating the state of macrophages, astrocytes, and $\mathrm{T}$ 
Table I The Immunomodulatory Mechanisms of Transplanted MSCs in Improving the Prognosis of SCI

\begin{tabular}{|c|c|c|c|c|c|c|c|c|}
\hline Species of MSCs & Source & Model & $\begin{array}{l}\text { Dose } \\
\text { (Number) }\end{array}$ & $\begin{array}{l}\text { Injection } \\
\text { Site }\end{array}$ & Infusion Time & Effect & Molecular Mechanism & Refs. \\
\hline Mice & Adipose & Mice & $1.0 \times 10^{6}$ & Intralesional & The day after $\mathrm{SCl}$ & $\begin{array}{l}\text { Promote functional } \\
\text { recovery }\end{array}$ & $\begin{array}{l}\text { Inhibit the infiltration of macrophages and reduce the } \\
\text { expression of TNF- } \alpha \text {, IL-I } \beta \text { and IL- } 6\end{array}$ & [109] \\
\hline Human & Bone marrow & Rat & N/A & Intralesional & 7 days after $\mathrm{SCl}$ & $\begin{array}{l}\text { Promote functional } \\
\text { recovery }\end{array}$ & $\begin{array}{l}\text { Reduce TNF- } \alpha \text {, IL-I } \beta \text {, IL-2, IL- } 6 \text { and IL-I2, increase the } \\
\text { levels of MIP-I } \alpha\end{array}$ & [110] \\
\hline Human & Bone marrow & Mice & $5.0 \times 10^{5}$ & Intralesional & $\begin{array}{l}\text { The day following } \\
\mathrm{SCl}\end{array}$ & $\begin{array}{l}\text { Improve locomotor } \\
\text { activity and suppress } \\
\text { SCl-related damage }\end{array}$ & $\begin{array}{l}\text { Up-regulate the levels of TSG-6, IL-I0, TGF- } \beta \text { and IL-4, } \\
\text { induce an AAM environment }\end{array}$ & {$[\mathrm{III}]$} \\
\hline Human & Bone marrow & Rat & $1.0 \times 10^{6}$ & Intralesional & 3 days after $\mathrm{SCl}$ & $\begin{array}{l}\text { Promote functional } \\
\text { recovery }\end{array}$ & $\begin{array}{l}\text { Activate M2 macrophages, inhibit MI macrophages, up- } \\
\text { regulate the levels of IL- } 4 \text { and IL-I3, down-regulate the } \\
\text { levels of TNF-a and IL- } 6\end{array}$ & [112] \\
\hline Rat & Bone marrow & Rat & $1.0 \times 10^{6}$ & Intravenous & 24 hours after $\mathrm{SCl}$ & $\begin{array}{l}\text { Promote functional } \\
\text { recovery }\end{array}$ & $\begin{array}{l}\text { Suppress the expression of pro-inflammatory cytokines } \\
\text { such as TNF- } \alpha \text { and IL-I } \beta\end{array}$ & [113] \\
\hline Human & Umbilical cord & Mice & $1.0 \times 10^{6}$ & Intralesional & I4 days after $\mathrm{SCl}$ & $\begin{array}{l}\text { Promote functional } \\
\text { recovery }\end{array}$ & $\begin{array}{l}\text { Promote the polarization of M2 macrophages, reduce the } \\
\text { expression of IL-7, IFN- } \gamma \text {, and TNF- } \alpha \text {, increase the } \\
\text { expression levels of IL- } 4 \text { and IL-I } 3\end{array}$ & [1 I4] \\
\hline Human & Umbilical cord & Mice & $1.0 \times 10^{5}$ & Intralesional & I day after $\mathrm{SCl}$ & $\begin{array}{l}\text { Improve locomotor } \\
\text { performance }\end{array}$ & Shift the macrophage phenotype to the $M 2$ phenotype & [115] \\
\hline Human & Deciduous teeth & Rat & $6.0 \times 10^{5}$ & Intralesional & The day after $\mathrm{SCl}$ & $\begin{array}{l}\text { Promote functional } \\
\text { recovery }\end{array}$ & $\begin{array}{l}\text { MCP-I and ED-Siglec- } 9 \text { secreted by MSCs synergistically } \\
\text { induce M } 2 \text { macrophages, suppress proinflammatory } \\
\text { mediators such as IL-I and TNF-a }\end{array}$ & [116] \\
\hline Rat & Peripheral blood & Rat & $2.0 \times 10^{4}$ & Intralesional & $\begin{array}{l}30 \text { minutes after } \\
\mathrm{SCl}\end{array}$ & $\begin{array}{l}\text { Promote functional } \\
\text { recovery }\end{array}$ & $\begin{array}{l}\text { Inhibit ThI7 cells, activate Treg cells, down-regulate the } \\
\text { levels of IL- } 6 \text { and IL-I7a }\end{array}$ & {$[117]$} \\
\hline
\end{tabular}


cells. ${ }^{130}$ Harnessing the ability of MSCs to regulate neuroinflammation might be a powerful tool to inhibit secondary injury, which is potentially good news for SCI patients (Table 2).

\section{MSCs for SCl: Macrophage-Mediated Neuroinflammation}

Macrophages are the most common immune cells at the lesion site and exert key roles in mediating the neuroinflammation during distinct periods post-SCI. Polarized macrophages can help facilitate angiogenesis and modulate connective tissue synthesis, which are the crucial elements of the damaged spinal cord repair, but can also cause deterioration of extracellular matrix and damage neurons and glia. ${ }^{134}$ The change of macrophages from a pro-inflammatory to an antiinflammatory, remodeling phenotype is considered to support the recovery of nerve function and the integrity of the injured tissue. ${ }^{31}$ Numerous studies have reported that macrophages co-cultured with MSCs have a cytokine secretion pattern similar to M2 macrophages, which are characterized by the up-regulation of IL-4 and IL-10 along with downregulation of TNF- $\alpha$, IL-1 $\beta$, and IL-12. ${ }^{135-138}$ A similar situation can also be observed in M0 macrophages co-cultured with MSC-conditioned medium (MSC-CM), indicating that soluble factors are essential for their immunomodulatory properties. ${ }^{139}$ These previous studies in vitro have raised our attentions about the polarization of macrophage in MSCs engraftment following SCI. Nakajima et $\mathrm{al}^{112}$ reported that after MSCs transplantation in the injured spinal cord, M2 macrophages and their associated cytokines IL-13 and IL-4 were significantly increased, while M1 macrophages and their associated cytokines TNF- $\alpha$ and IL- 6 were significantly decreased, resulting in axonal regeneration, inhibition of glial scar formation, and increased myelin sparing. Subsequently, it was shown in rat models of SCI that exosome (exo) derived from adipose-derived MSCs could also shift the macrophage phenotype from M1 to M2, accompanied by downregulation of the pro-inflammatory cytokines IFN- $\gamma$ and TNF- $\alpha$, and this promoted a pro-regenerative environment. ${ }^{140}$ To date, the accumulated evidence confirms that MSCs can skew the balance between M1/M2 macrophages towards the M2 phenotype, thereby facilitating functional neurological improvement post-SCI. ${ }^{141,142}$

Study investigating the mechanism involved found that this effect was associated with some soluble factors secreted by MSCs. ${ }^{134}$ Stimulated MSCs can significantly secrete numerous cytokines including TGF- $\beta$, indoleamine 2,3-dioxygenase (IDO), prostaglandin E2 (PGE2), IL-4, and IL-6 following stimulation by inflammatory mediators. These diverse soluble factors play an essential role in shifting the macrophage phenotype from M1 to M2. ${ }^{134,143-150}$ Notably, we previously showed that inflammatory macrophages could activate the NF- $\mathrm{B}$ pathway of peripheral blood-derived mesenchymal stem cells (PB-MSCs) by releasing TNF- $\alpha$ and IL-1 $\beta$, resulting in the up-regulation of IL1-RA of PBMSCs, which could induce the macrophage polarization towards M2 phenotype. ${ }^{151}$ In response to inflammatory stimuli, MSCs up-regulated the expression levels of tumor necrosis factor-induced protein 6, which could reduce the nuclear translocation of NF- $\mathrm{kB}$ by binding to the resident macrophages' CD44 receptor, thereby weakening the macrophagesmediated inflammatory cascade. ${ }^{143,152}$ Moreover, IL-10 secreted by MSCs is likely to shift the macrophage phenotype towards anti-inflammatory M2 by activating Janus kinase (JAK)/signal transducer and activator of transcription (STAT) 3 signaling. ${ }^{153-155}$

In summary, MSCs have emerged as promising immune-modulators of macrophages polarization by modulating the production of distinct cytokines. Identifying the regulatory factors and key pathways of MSCs-mediated macrophage polarization is the key to shifting the macrophage phenotype from M1 to M2, thus creating an anti-inflammatory microenvironment for axonal extension and functional recovery. However, the specific effects of different subtypes on functional recovery should be fully considered when designing macrophage polarization as an immunomodulatory strategy.

\section{MSCs for SCl: Astrocyte-Mediated Neuroinflammation}

Astrocytes are the most abundant glial cells in the CNS, and they are essential for the homeostasis of the CNS. ${ }^{156}$ As mentioned above, reactive astrocytes are highly heterogeneous after SCI and have been identified in two distinct categories, A1 and A2. Liddelow et al $^{157}$ have reported that classically activated neuroinflammatory microglia shift astrocytes to the A1 phenotype by releasing TNF- $\alpha$, IL- $1 \alpha$, and $\mathrm{C} 1 \mathrm{q}$, which together are sufficient and necessary. A1 astrocytes lose most of their original functions and show new features, including rapidly killing the neurons and mature differentiated oligodendrocytes. ${ }^{158}$ Therefore, efforts should be focused on inhibiting the activation of A1 astrocytes for 
Table 2 Completed Clinical Trials of MSCs in the Treatment of SCI

\begin{tabular}{|c|c|c|c|c|c|c|c|c|}
\hline $\begin{array}{l}\text { Clinical } \\
\text { Trials. Gov } \\
\text { Identifier }\end{array}$ & Status & $\begin{array}{l}\text { Phase(s) (No. } \\
\text { Enrolled) }\end{array}$ & $\begin{array}{l}\text { Completion } \\
\text { Date }\end{array}$ & $\begin{array}{l}\text { Primary End } \\
\text { Point }\end{array}$ & $\begin{array}{l}\text { Ages } \\
\text { (Years) }\end{array}$ & Intervention & Transplantation & Findings \\
\hline NCT02482194 & Completed & I $(\mathrm{N}=9)$ & Mar 2016 & Safety & $18 \sim 50$ & Autologous BM-MSCs & Intrathecal & $\begin{array}{l}\text { Intrathecal injection of BMMSCs is safe with no } \\
\text { serious adverse event }\end{array}$ \\
\hline NCT0 I67644I & Terminated & $\| / / I I I(N=20)$ & Mar 202I & Safety, ASIA score & $16 \sim 65$ & Autologous BM-MSCs & Intrathecal & $\begin{array}{l}\text { Patients receiving BM-MSCs demonstrate } \\
\text { improved in the muscle tension and in ADL, as } \\
\text { well as significant MRI and electrophysiological } \\
\text { changes }\end{array}$ \\
\hline NCT0248I440 & Completed & $\mathrm{I} / \mathrm{II}(\mathrm{N}=102)$ & Mar 2020 & Safety, ASIA score & $18 \sim 65$ & Allogeneic hUC-MSCs & Intrathecal & $\begin{array}{l}\text { Intrathecal injection of hUC-MSCs is safe with } \\
\text { no serious adverse event }\end{array}$ \\
\hline NCT02152657 & Completed & $\mathrm{N} / \mathrm{A}(\mathrm{N}=5)$ & Dec 2016 & Safety, MRI & $18 \sim 65$ & Autologous MSCs & Percutaneous & N/A \\
\hline NCT0298I576 & Completed & $I / I I(N=14)$ & Jan 2019 & $\begin{array}{l}\text { Safety and efficacy, } \\
\text { ASIA score, MRI }\end{array}$ & $18 \sim 70$ & $\begin{array}{l}\text { Autologous BM-MSCs } \\
\text { and AD-MSCs }\end{array}$ & Intrathecal & N/A \\
\hline NCT02570932 & Completed & $\|(\mathrm{N}=10)$ & Dec 2017 & IANR-SCIFRS & $18 \sim 70$ & Autologous BM-MSCs & Intrathecal & $\begin{array}{l}\text { Patients receiving BM-MSCs show variable } \\
\text { clinical improvement in sensitivity, motor } \\
\text { power, spasms, spasticity, neuropathic pain, } \\
\text { sexual function or sphincter dysfunction } \\
\text { without any adverse event }\end{array}$ \\
\hline NCT01769872 & Completed & $\mid / I I(N=15)$ & Jan 2016 & $\begin{array}{l}\text { Safety and effect, } \\
\text { ASIA score }\end{array}$ & 19 70 & Autologous AD-MSCs & Intrathecal & N/A \\
\hline NCTOI 274975 & Completed & I $(\mathrm{N}=8)$ & Feb 2010 & Safety & $19 \sim 60$ & Autologous AD-MSCs & Intravenous & N/A \\
\hline NCT0I 624779 & Completed & I $(N=15)$ & May 2014 & MRI & $19 \sim 70$ & Autologous AD-MSCs & Intrathecal & $N / A$ \\
\hline NCT04288934 & Completed & I $(\mathrm{N}=20)$ & Sep 2020 & $\begin{array}{l}\text { ASIA score, } \\
\text { ISNCSCI, SCIM III }\end{array}$ & 18 70 & $\begin{array}{l}\text { Autologous BM-MSCs, } \\
\text { WJ-MSCs }\end{array}$ & Intralesional. & N/A \\
\hline NСT01873547 & Completed & III (N=300) & Dec 2015 & Safety, ASIA score & $20 \sim 65$ & Allogeneic UC-MSCs & Intrathecal & N/A \\
\hline NCT01909154 & Completed & I $(\mathrm{N}=12)$ & Mar 2015 & Safety & $18 \sim 60$ & Autologous BM-MSCs & Intrathecal & $\begin{array}{l}\text { Intrathecal administration of BM-MSCs is safe } \\
\text { with no adverse events }\end{array}$ \\
\hline NCT00816803 & Completed & I/II $(\mathrm{N}=80)$ & Dec 2008 & Safety, MRI & $10 \sim 36$ & Autologous BM-MSCs & Intrathecal & $\begin{array}{l}\text { Intrathecal injection of BM-MSC is safe with no } \\
\text { long-term cell therapy-related side effects }\end{array}$ \\
\hline
\end{tabular}




\begin{tabular}{|c|c|c|c|c|c|c|c|c|}
\hline NCT02165904 & Completed & I $(\mathrm{N}=10)$ & May 2016 & ASIA score & $18 \sim 70$ & Autologous BM-MSCs & Intrathecal & $\begin{array}{l}\text { Patients treated with BM-MSCs show } \\
\text { improvements in sensitivity, motor function, } \\
\text { sexual function and urinary control }\end{array}$ \\
\hline NCT02510365 & Unknown & I $(\mathrm{N}=20)$ & Dec 2021 & Safety and efficacy & $18 \sim 65$ & Allogeneic UC-MSCs & Intralesional & $\begin{array}{l}\text { UC-MSCs transplantation is safe with no } \\
\text { obvious adverse symptoms }\end{array}$ \\
\hline NCTOI 393977 & Unknown & II $(\mathrm{N}=60)$ & May 2012 & EET & $20 \sim 50$ & Allogeneic UC-MSCs & Intrathecal & $\begin{array}{l}\text { Patients receiving UC-MSCs demonstrate } \\
\text { improved self-care ability, muscular tension, } \\
\text { maximum urinary flow rate as well as maximum } \\
\text { bladder capacity }\end{array}$ \\
\hline NCTOII62915 & Suspended & $I(N=10)$ & May 2014 & Safety & $18 \sim 65$ & Autologous BM-MSCs. & Intrathecal & N/A \\
\hline NCT0I325I03 & Completed & $N / A(N=14)$ & Dec 2012 & Safety & $18 \sim 50$ & Autologous BM-MSCs & Intralesional & $\begin{array}{l}\text { Patients treated with BM-MSCs show } \\
\text { improvement in both urinary and nervous } \\
\text { system function and AISA score }\end{array}$ \\
\hline NCT03003364 & Completed & $I / I I(N=10)$ & Feb 2020 & Safety & $18 \sim 65$ & Allogeneic WJ-MSCs & Intrathecal & $\begin{array}{l}\text { Intrathecal transplantation of WJ-MSCs is safe } \\
\text { with no significant side effects }\end{array}$ \\
\hline NCT01694927 & Unknown & II $(\mathrm{N}=30)$ & Jun 2014 & Safety & $2 \sim 65$ & Autologous MSCs & Intrathecal & $N / A$ \\
\hline NCT02574572 & Unknown & $I(N=10)$ & Jun 2020 & MRI & $18 \sim 65$ & Autologous MSCs & Intralesional & $N / A$ \\
\hline NCTOI 446640 & Unknown & $I / I I(N=20)$ & Jun 2014 & Safety & $16 \sim 60$ & Autologous BM-MSCs & Intrathecal & N/A \\
\hline NCT02688049 & Unknown & $I / I I(N=30)$ & Dec 2021 & $\begin{array}{l}\text { ASIA score, SSEP, } \\
\text { MEP }\end{array}$ & $18 \sim 65$ & Autologous BM-MSCs & Intralesional & $N / A$ \\
\hline NCT02352077 & Unknown & I $(\mathrm{N}=30)$ & Dec 2021 & Safety & $18 \sim 65$ & Autologous BM-MSCs & Intralesional & N/A \\
\hline NCT05018793 & Suspended & $\mathrm{I}(\mathrm{N}=15)$ & Dec 2025 & Safety & $\begin{array}{l}\text { Child, } \\
\text { adult, } \\
\text { older }\end{array}$ & Autologous AD-MSCs & Intrathecal & $\begin{array}{l}\text { Intrathecal administration of AD-MSCs is safe } \\
\text { with no adverse events }\end{array}$ \\
\hline NCT042|3|3| & Unknown & $\mathrm{N} / \mathrm{A}(\mathrm{N}=42)$ & Jan 2021 & $\begin{array}{l}\text { Neurologic } \\
\text { function score, } \\
\text { ASIA score }\end{array}$ & $20 \sim 65$ & Allogeneic hUC-MSCs & Intravenous & N/A \\
\hline
\end{tabular}

Abbreviations: ASIA, American spinal injury association; ISNCSCI, international standards for neurological classification of SCl; MEP, motor evoked potentials; SSEP, somatosensory evoked potentials; MRI, magnetic resonance imagin SCIM, spinal cord independence measure; IANR-SCIFRS, neurorestoratology-spinal cord injury functional rating scale; N/A, not applicable; EET, electromyogram and electroneurophysiologic test; $h$ UC-MSCs, human umbilical cordderived mesenchymal stem cells; UC-MSCs, umbilical cord derived mesenchymal stem cells; AD-MSCs, adipose tissue-derived mesenchymal stem cells; WJ-MSCs, wharton's jelly mesenchymal stem cells. 
the treatment of SCI. In response to lipopolysaccharide (LPS), A1-related cytokine, IL-1 $\beta$ and TNF- $\alpha$, is significantly upregulated, but this is inhibited when astrocytes are pre-treated with MSC-CM. ${ }^{159}$ Recently, study has shown that BMMSC-exo transplanted into contusive SCI rat models could significantly reduce the number of A1 neurotoxic astrocytes by inhibiting the activation of inflammatory macrophages, thereby effectively promoting angiogenesis and axonal regeneration, and reducing neuronal apoptosis and inflammatory response. Furthermore, Wang et al found that BM-MSCs and BMMSC-exo could both directly hinder astrocytes from polarizing toward the pro-inflammatory A1 phenotype after SCI by inhibiting the nuclear translocation of NF-kb p65, thereby reducing the lesion area and levels of IL-1 $\beta$, TNF- $\alpha$, and IL- $1 \alpha$, as well as increasing the expression of myelin basic protein, marker of neuronal nuclei, and synaptophysin. ${ }^{160,161}$ These results suggest that MSCs and MSC-exo can not only directly inhibit the formation of A1 astrocytes after SCI, but also indirectly suppress the polarization of A1 astrocytes by preventing the activation of inflammatory macrophages.

JAK/STAT3 pathway activation is critical for astrocyte proliferation, polarization, and growth. ${ }^{84,89,162}$ After CNS injury, IL-6 secreted by transplanted MSCs might mediate the polarization of A2 astrocytes by activating JAK/STAT3 signaling, thus significantly improving the neurological recovery. ${ }^{163}$ Besides, in models of systemic LPS activation, IL10 secreted by M2 macrophages can induce astrocytes polarization toward the anti-inflammatory A2 phenotype, accompanied by significant up-regulation of TGF- $\beta$, which could also greatly shift the macrophage phenotype towards M2, with lower expression of IL- 6 and IL-1 $\beta$ and high levels of CX3CR1 and IL-4R $\alpha$. Hence, the interaction between M2 macrophages and A2 astrocytes is beneficial to generate an anti-inflammatory and reparative microenvironment. ${ }^{164}$ As mentioned above, MSCs and MSC-exo can drive macrophage toward an M2 phenotype. Taken together, it is possible that MSCs and MSC-exo exert effects on A2 astrocytes not only in a direct way but also mediated through the activation of M2 macrophages, thereby exerting a powerful immunosuppressive function and breaking the inflammatory cascade reaction after SCI. Other studies have revealed that in response to TGF- $\beta$, PI3K/AKT signaling in astrocytes modulates various physiological events, such as activation, proliferation, growth, and survival. PI3K/AKT pathway activation also induces astrocyte polarization toward the A2 phenotype; it is well known that MSCs can constitutively produce TGF$\beta{ }^{165-169}$ Taken together, the evidence suggests that TGF- $\beta$ secreted by MSCs may mediate astrocyte polarization in the A2 phenotype through the PI3K/AKT pathway. However, more specific studies are needed to clarify this issue.

\section{MSCs for SCl: T Lymphocyte-Mediated Neuroinflammation}

The excessive inflammatory Th1 and Th17 phenotypes observed following SCI tilt the scale toward the pro-inflammatory environment, which exacerbates the damage to neural tissue within weeks or even months. ${ }^{49}$ We have recently demonstrated that after direct culture of CD4+ T cells and PB-MSCs in vitro, the Th17/Treg ratio and levels of proinflammatory cytokines IL-17 and IL-6 were significantly down-regulated, while the levels of anti-inflammatory cytokines TGF- $\beta$, IL-10 and Foxp3 were significantly up-regulated. ${ }^{135}$ Moreover, BM-MSCs could also suppress the proliferation, activation, and differentiation of Th17 and Th1 cells and induce Treg polarization in vitro. ${ }^{170}$ After interacting with dendritic cells, MSCs shift from the Th1 to Th2 subtype, and this is accompanied by higher levels of anti-inflammatory cytokines. ${ }^{171}$ MSC-exo is also reported inhibiting T cell proliferation and activation and shift their phenotype towards the anti-inflammatory Treg, with a corresponding beneficial change in the cytokine profile. ${ }^{92,172,173}$ Altogether, these results suggest that MSCs can inhibit Th1 and Th17 cell differentiation and induce Th 2 and Treg cells in vitro. Notably, our team has found that PB-MSCs transplanted into rat models of SCI caused decreases in CD4 + IL17 + Th17 cells along with their associated cytokines IL-6 and IL-21, and increases in the numbers of CD4 + CD25 + Foxp3 + Treg cells and their associated cytokines Foxp3, TGF- $\beta$, and IL-10; these changes ultimately contributed to improved functional recovery. ${ }^{117}$ Furthermore, various activated CD4+ T cell subtypes can form a complex network regulatory system by coordinating and antagonizing other immune cell types. For example, Th1 cells can induce the differentiation of macrophages into M1 phenotype, while Th2 cells can induce the polarization of M2 macrophages that are involved in the induction of Treg. Therefore, in addition to directly regulating each immune cell, the application of MSCs may provide an anti-inflammatory and stable environment for nerve tissue repair by breaking this inflammatory cascade reaction. 
Further investigations reveal that MSCs stimulated by IFN- $\gamma$ can significantly up-regulate IDO expression levels; this results in tryptophan degradation that inhibits the allogeneic T cell response, promotes Th2 to secrete IL-4, and prevents Th1 from producing IFN- $\gamma .{ }^{171,174}$ MSCs are also able to suppress T cell proliferation and the secretion of related inflammatory cytokines by producing nitric oxide and PGE2, and PGE2 can also prevent CD4+ T cells from differentiating into Th17 cells. ${ }^{175-178}$ Moreover, studies have demonstrated that MSCs can exert their inhibitory effects on CD4+ T cell differentiation towards Th1 and Th17, possibly due to induction of Treg and IL-10 secretion. ${ }^{170,179}$ Furthermore, MSC-mediated Treg induction can be inhibited by a TGF- $\beta$ blocker, indicating that TGF- $\beta$ secreted by MSCs plays a critical role in the differentiation of CD4+ T cells into Treg. ${ }^{180,181}$ Despite the fact that soluble factors are involved in Treg induction, ICOSL (inducible T cell costimulatory ligand) expression in MSCs is also essential for contact-dependent modulation of MSC-mediated Treg polarization. ${ }^{182}$ These results suggest that MSC-mediated CD4+ T cells polarization may be modulated by different mechanisms depending both on soluble factors and cell-surface proteins.

In conclusion, the immunomodulatory role of MSCs in CNS injury involves multiple immune cell types. These immune cells can modulate MSCs gene expression, which subsequently inhibits the immune response of these innate and adaptive immune cells to produce an immunotolerant and permissive micro-environment (Figure 2). All the achievements in MSCs engraftment bring hope to the successful transformation, but in vivo models of SCI currently used by researchers are mainly small rodents, such as rats and mice. Although this animal model is cost-effective and easy to feed, it is necessary to use larger animal models, such as non-human primates to further confirm the safety and efficacy of MSCs in improving nerve regeneration after nerve injury because their size and neuroanatomical structure are similar to those of human specimens. ${ }^{183}$ Furthermore, in order to enhance the therapeutic effect of MSCs, more research is needed in the future to determine the ideal number of cells for transplantation, cell source, timing of administration, and route of administration.

\section{Prospective}

Although transplanted MSCs are able to improve anatomical and locomotor recovery after SCI, the post-injury inflammatory and toxic environment is not suitable for the survival of grafted cells. ${ }^{195,196}$ Therefore, any strategy that enhances the viability and proliferation of transplanted MSCs is of great value. ${ }^{197,198}$ It is noteworthy that preconditioning can effectively enhance the immunomodulatory and survival ability of MSCs in vitro and in vivo (Figure 3 ) $^{127}$ (Table 3). For example, MSCs pretreated with cobalt chloride could improve their homing ability by up-regulating levels of hypoxia-inducible factor-1 $\alpha$ and CXCR4; simultaneously they can decrease their apoptosis rate by down-regulating caspase-3 and Bcl-2 levels. These hypoxic MSCs can also significantly inhibit macrophage polarization toward the proinflammatory M1 phenotype, along with lower levels of pro-inflammatory cytokines TNF- $\alpha$ and IL-1 $\beta .{ }^{186}$ Furthermore, MSC-exo harvested from hypoxic MSCs could significantly shift the macrophage phenotype from M1 to M2 by

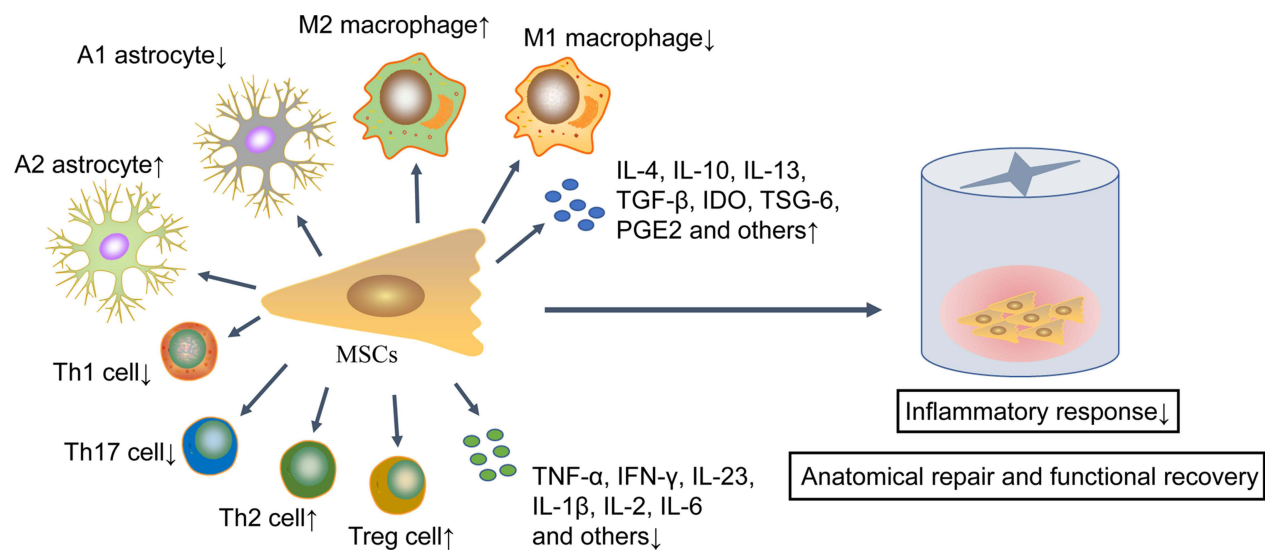

Figure 2 MSCs improve SCl prognosis via immunomodulatory effects. These transplanted MSCs inhibit an excessive inflammatory response by up-regulating antiinflammatory immune cells and associated cytokines and down-regulating the pro-inflammatory immune cells and associated cytokines, thereby promoting anatomical repair and functional recovery.

Notes: $\uparrow$, promotion; $\downarrow$, inhibition. 


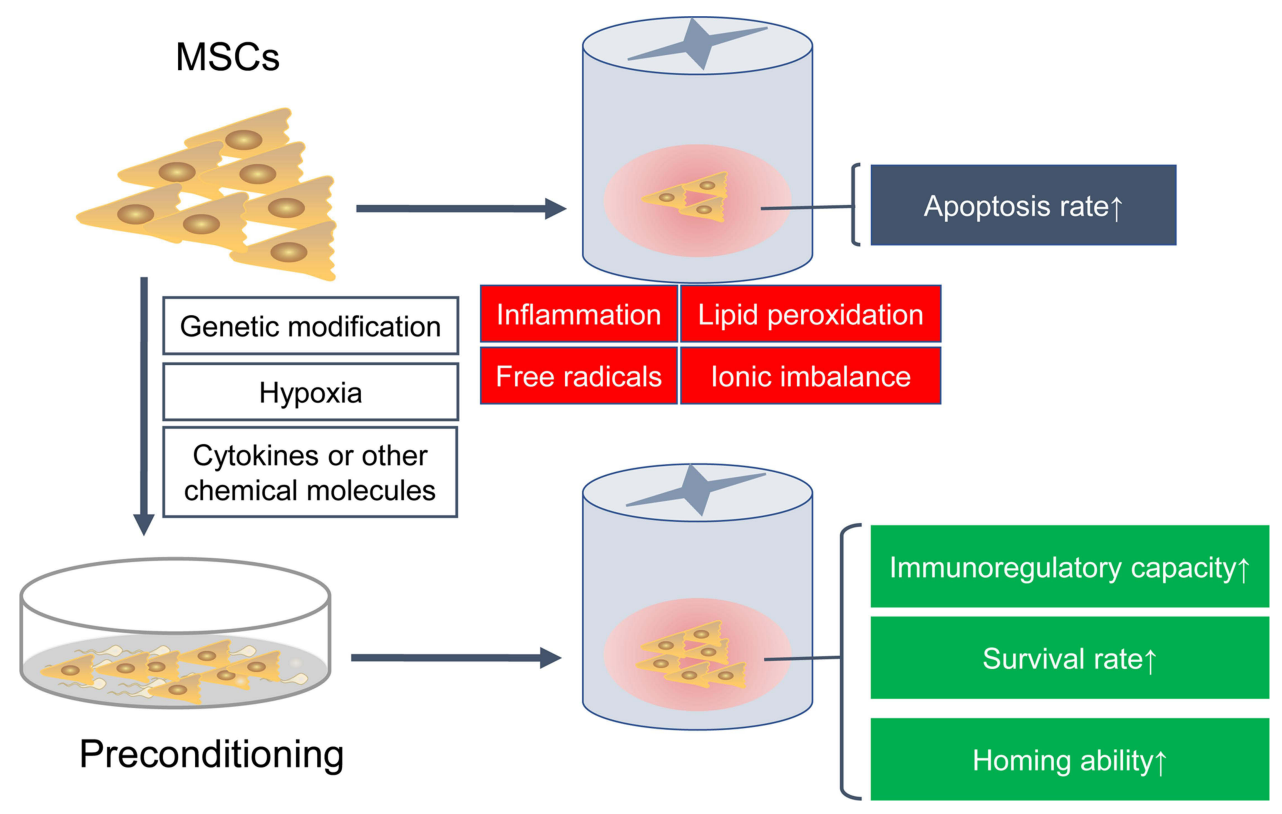

Figure 3 Preconditioning enhances the immunomodulatory ability and survival rate of $\mathrm{MSCs}$ in $\mathrm{SCl}$. After $\mathrm{SCl}$, the local harsh microenvironment causes a large amount of transplanted MSCs apoptosis. Various preconditioning strategies, including genetic modification, cytokines, hypoxia or other chemical molecules, can improve the immunomodulatory capacity, survival rate and homing ability of transplanted MSCs.

Note: $\uparrow$, promotion.

modulating the TLR4/NF-kB/PI3K/Akt pathway, thereby promoting functional and behavioral recovery. ${ }^{188}$ Furthermore, moringin-pretreated MSCs significantly down-regulated COX-2 and IL-1 $\beta$ levels in the spinal cord and reduced cellular apoptosis by decreasing the expression levels of Bax, caspase-3, and caspase- 9 and increasing levels of the anti-apoptotic protein Bcl-2. ${ }^{185}$ In another study, it was revealed that the treatment of MSCs with IL-1 $\beta$ and IFN- $\gamma$ enhanced their ability to induce macrophage polarization towards an anti-inflammatory M2 phenotype in comparison to MSCs treated with nothing. ${ }^{199}$ These results indicate that hypoxia or cytokine preconditioning has a strong cytoprotective effect, which can help them adapt to the new environment during the acute phase of transplantation.

Gene modification might serve as another unique way to further improve MSCs immunomodulatory capacity. IL-35 is necessary for Treg to exert the maximum regulatory activity in vivo and in vitro. ${ }^{200,201}$ MSCs over-expressing IL-35 could significantly increase the percentage of CD4 + CD25 + Treg and suppress the effects of Th1 and Th17 cells. One study showed that compared with an untreated MSCs group, expression of the pro-inflammatory cytokine IL-17A was significantly down-regulated, while IL-10 was significantly up-regulated in the IL-35-transduced MSCs group. ${ }^{201}$ Additionally, MSCs over-expressing IL-13 could significantly shift the macrophage phenotype to anti-inflammatory M2, thereby promoting the functional and histopathological recovery of SCI mouse models. ${ }^{202}$ Although genetic modification of MSCs can promote cell survival and immunomodulatory capacity, safety concerns are the main limitations for the future therapeutic application of genetically modified MSCs, as viral vector integration may cause tumorigenesis in recipients after long-term treatment.

Taken together, the inflammatory cascade is a major contributor to secondary damage and directly affects disease progression. Macrophages, astrocytes, and T cells are the major cell types involved in SCI neuroinflammation, but no existing therapy directly targets neuroinflammation. Over the past few decades, MSCs have emerged as attractive, transplantable, and reparative cells that can not only directly modulate the activation of macrophages, astrocyte, and $\mathrm{T}$ cells, but also can break their complex inflammatory cascade reaction, thereby providing an anti-inflammatory and permissive microenvironment for CNS regeneration and repair. Considering that a pro-inflammatory and toxic microenvironment has harmful effects on the survival and immunoregulatory capacity of transplanted MSCs, pretreatment may enhance the ability of MSCs and further improve the ability to inhibit robust inflammation. However, further researches 
Table 3 The Immunosuppressive Effect of Pretreated MSCs and Extracellular Vesicles Secreted by MSCs in SCI

\begin{tabular}{|c|c|c|c|c|c|c|c|c|c|}
\hline Source & Pretreatment & $\begin{array}{l}\text { Dose } \\
\text { (Number) }\end{array}$ & Model & Way & Infusion time & $\begin{array}{l}\text { Secretion } \\
\text { of MSCs }\end{array}$ & Immunomodulatory Mechanism & Effect & Refs. \\
\hline $\begin{array}{l}\text { Human umbilical } \\
\text { cord }\end{array}$ & Hypoxia & $1 \times 10^{5}$ & Rat & Intralesional & N/A & N/A & $\begin{array}{l}\text { Up-regulate the levels of regenerative } \\
\text { neurotrophic factors, inhibit microglial/ } \\
\text { macrophage infiltration }\end{array}$ & $\begin{array}{l}\text { Promote functional } \\
\text { recovery }\end{array}$ & [184] \\
\hline Human gingiva & $\begin{array}{l}\text { Vesicular } \\
\text { moringin } \\
\text { nanostructures }\end{array}$ & $1 \times 10^{6}$ & Mice & Intravenous & Ih hour after $\mathrm{SCl}$ & N/A & $\begin{array}{l}\text { Increase the levels of anti-inflammatory } \\
\text { cytokines such as IL- } 10 \text { and TGF- } \beta\end{array}$ & $\begin{array}{l}\text { Promote functional } \\
\text { recovery }\end{array}$ & {$[185]$} \\
\hline Rat bone marrow & Hypoxia & $1 \times 10^{6}$ & Rat & Intralesional & $\begin{array}{l}\text { The day following } \\
\mathrm{SCl}\end{array}$ & N/A & $\begin{array}{l}\text { Down-regulate the levels of pro- } \\
\text { inflammatory cytokines such as TNF- } \alpha \text {, IL- } \\
\text { I } \beta \text { and IL- } 6\end{array}$ & $\begin{array}{l}\text { Improve motor and } \\
\text { sensory function }\end{array}$ & {$[186]$} \\
\hline $\begin{array}{l}\text { Human umbilical } \\
\text { cord }\end{array}$ & N/A & I, 2, 3ug & Rat & Intrathecal & $24 \mathrm{~h}$ after $\mathrm{SCl}$ & EVs & $\begin{array}{l}\text { Decrease the expression of caspase-I, IL- } \\
\text { I, IL-I8 and TNF- } \alpha\end{array}$ & $\begin{array}{l}\text { Improve locomotor } \\
\text { function }\end{array}$ & [187] \\
\hline $\begin{array}{l}\text { Human umbilical } \\
\text { cord }\end{array}$ & N/A & $25 \mu \mathrm{g}$ & Mice & Intravenous & $\begin{array}{l}\mathrm{I} \text { h and } 7 \text { days } \\
\text { after } \mathrm{SCl}\end{array}$ & $\mathrm{N}-\mathrm{NVs}$ & $\begin{array}{l}\text { N-NVs shift the balance from } M I \text { to } M 2 \\
\text { macrophages }\end{array}$ & $\begin{array}{l}\text { Promote functional } \\
\text { recovery }\end{array}$ & [142] \\
\hline Rat bone marrow & Hypoxia & $200 \mu \mathrm{g}$ & Mice & Intravenous & $\begin{array}{l}\text { The day following } \\
\mathrm{SCl}\end{array}$ & Exosome & $\begin{array}{l}\text { Promote microglia/macrophage } \\
\text { polarization from } M I \text { to } M 2 \text { phenotype, } \\
\text { inhibit the TLR4 pathway }\end{array}$ & $\begin{array}{l}\text { Promote functional } \\
\text { recovery }\end{array}$ & {$[188]$} \\
\hline Rat bone marrow & N/A & $2.5 \times 10^{9}$ & Rat & Intravenous & I week after $\mathrm{SCl}$ & Exosome & $\begin{array}{l}\text { Increase the production of anti- } \\
\text { inflammatory cytokines, block } \mathrm{M} 2 \\
\text { macrophages from converting to an } \mathrm{MI} \\
\text { pro-inflammatory activation state }\end{array}$ & N/A & [189] \\
\hline Rat bone marrow & N/A & N/A & Rat & Intravenous & $\begin{array}{l}7 \text { consecutive days } \\
\text { after } \mathrm{SCl}\end{array}$ & Exosome & $\begin{array}{l}\text { Increase the expression levels of anti- } \\
\text { inflammatory factors such as IL-I0 and IL- } \\
4 \text {, decrease the levels of TNF-a, IL-Ib and } \\
\text { MCP-I }\end{array}$ & $\begin{array}{l}\text { Promote functional } \\
\text { recovery }\end{array}$ & [190] \\
\hline $\begin{array}{l}\text { Human umbilical } \\
\text { cord }\end{array}$ & $\begin{array}{l}\text { Overexpression } \\
\text { of NT-3 }\end{array}$ & $1 \times 10^{6}$ & Rat & Intralesional & I week after $\mathrm{SCl}$ & NT-3 & $\begin{array}{l}\text { Reduce the accumulation of } \\
\text { immunoreactive macrophages/microglia }\end{array}$ & $\begin{array}{l}\text { Promote functional } \\
\text { recovery }\end{array}$ & {$[191,192]$} \\
\hline Mice bone marrow & $\begin{array}{l}\text { Overexpression } \\
\text { of IGF-I }\end{array}$ & $1 \times 10^{6}$ & Mice & Intralesional & N/A & IGF-I & $\begin{array}{l}\text { Up-regulate antioxidant defense genes and } \\
\text { the expression levels of } \mathrm{Mrcl}, \mathrm{Nfe} 2 \mathrm{~L} 2 \text {, } \\
\text { reduce the levels of MDA, nitrite }\end{array}$ & $\begin{array}{l}\text { Promote functional } \\
\text { recovery }\end{array}$ & [193] \\
\hline
\end{tabular}


Table 3 (Continued).

\begin{tabular}{|c|c|c|c|c|c|c|c|c|c|}
\hline Source & Pretreatment & $\begin{array}{l}\text { Dose } \\
\text { (Number) }\end{array}$ & Model & Way & Infusion time & $\begin{array}{l}\text { Secretion } \\
\text { of MSCs }\end{array}$ & Immunomodulatory Mechanism & Effect & Refs. \\
\hline Rat bone marrow & N/A & $200 \mu g$ & Rat & Intravenous & $\begin{array}{l}\text { The day following } \\
\mathrm{SCl}\end{array}$ & Exosome & $\begin{array}{l}\text { Suppress the activation of microglia and } \\
\text { A I astrocytes, decrease the levels of TNF- } \\
\text { a, IL-Ib and IL- } 6\end{array}$ & $\begin{array}{l}\text { Promote functional } \\
\text { recovery }\end{array}$ & [194] \\
\hline Rat bone marrow & N/A & $40 \mu g$ & Rat & Intravenous & $\begin{array}{l}30 \text { minutes after } \\
\mathrm{SCl}\end{array}$ & Exosome & $\begin{array}{l}\text { Reduce the proportion of AI astrocytes } \\
\text { and the levels of TNF- } \alpha,|\mathrm{IL}-| \alpha \text { and IL-I } \beta\end{array}$ & $\begin{array}{l}\text { Promote functional } \\
\text { recovery }\end{array}$ & {$[161]$} \\
\hline
\end{tabular}

Abbreviations: EVs, extracellular vehicles; N-NVs, normal MSC-derived nanovesicles; NT-3, neurotrophin-3; IGF-I, insulin-like growth factor I; Mrcl, recombinant mannose receptor C type I; Nfe2L2, recombinant nuclear factor erythroid 2 like protein 2; MDA, malondialdehyde; N/A, not applicable. 
are needed to monitor the tumorigenic risk of engrafted gene-modified MSCs. Despite these promising avenues of research, further work is needed to improve our knowledge of molecular mechanisms and optimal transplantable conditions. Once these issues are addressed, MSCs are likely to be administered in clinical practice to relieve SCI patient suffering and enhance their quality of life.

\section{Acknowledgments}

All authors thank Charlesworth Group for English polishing.

\section{Funding}

This work was supported by grants from the National Natural Science Foundation of China (No. 81960299), and the Guizhou Provincial Science and Technology Foundation (No. [2020]1Y324).

\section{Disclosure}

The authors declare that they have no competing interests.

\section{References}

1. Liu WZ, Ma ZJ, Li JR, Kang XW. Mesenchymal stem cell-derived exosomes: therapeutic opportunities and challenges for spinal cord injury. Stem Cell Res Ther. 2021;12(1):102. doi:10.1186/s13287-021-02153-8

2. Yang B, Zhang F, Cheng F, et al. Strategies and prospects of effective neural circuits reconstruction after spinal cord injury. Cell Death Dis. 2020;11(6):439. doi:10.1038/s41419-020-2620-z

3. Suzuki H, Sakai T. Current concepts of stem cell therapy for chronic spinal cord injury. Int J Mol Sci. 2021;22(14):7435. doi:10.3390/ ijms 22147435

4. Singh A, Tetreault L, Kalsi-Ryan S, Nouri A, Fehlings MG. Global prevalence and incidence of traumatic spinal cord injury. Clin Epidemiol. 2014;6:309-331. doi:10.2147/CLEP.S68889

5. Fakhri S, Abbaszadeh F, Jorjani M. On the therapeutic targets and pharmacological treatments for pain relief following spinal cord injury: a mechanistic review. Biomed Pharmacother. 2021;139:111563.

6. Liu X, Zhang Y, Wang Y, Qian T. Inflammatory response to spinal cord injury and its treatment. World Neurosurg. 2021;155:19-31. doi:10.1016/j.wneu.2021.07.148

7. Torregrossa F, Salli M, Grasso G. Emerging therapeutic strategies for traumatic spinal cord injury. World Neurosurg. 2020;140:591-601. doi:10.1016/j.wneu.2020.03.199

8. Han T, Song P, Wu Z, et al. MSC secreted extracellular vesicles carrying TGF-beta upregulate Smad 6 expression and promote the regrowth of neurons in spinal cord injured rats. Stem Cell Rev Rep. 2021. doi:10.1007/s12015-021-10219-6

9. Abbaszadeh F, Fakhri S, Khan H. Targeting apoptosis and autophagy following spinal cord injury: therapeutic approaches to polyphenols and candidate phytochemicals. Pharmacol Res. 2020;160:105069. doi:10.1016/j.phrs.2020.105069

10. Lin J, Xiong Z, Gu J, et al. Sirtuins: potential therapeutic targets for defense against oxidative stress in spinal cord injury. Oxid Med Cell Longev. 2021;2021:7207692. doi:10.1155/2021/7207692

11. Hachem LD, Fehlings MG. Pathophysiology of spinal cord injury. Neurosurg Clin N Am. 2021;32(3):305-313. doi:10.1016/j.nec.2021.03.002

12. Piri SM, Ghodsi Z, Shool S, et al. Macrophage migration inhibitory factor as a therapeutic target after traumatic spinal cord injury: a systematic review. Eur Spine J. 2021;30(6):1474-1494. doi:10.1007/s00586-021-06718-2

13. Vafaei-Nezhad S, Pour Hassan M, Noroozian M, et al. A review of low-level laser therapy for spinal cord injury: challenges and safety. $J$ Lasers Med Sci. 2020;11(4):363-368. doi:10.34172/jlms.2020.59

14. David S, Lopez-Vales R. Bioactive lipid mediators in the initiation and resolution of inflammation after spinal cord injury. Neuroscience. 2021;466:273-297. doi:10.1016/j.neuroscience.2021.04.026

15. Chio JCT, Xu KJ, Popovich P, David S, Fehlings MG. Neuroimmunological therapies for treating spinal cord injury: evidence and future perspectives. Exp Neurol. 2021;341:113704. doi:10.1016/j.expneurol.2021.113704

16. Takami T, Shimokawa N, Parthiban J, Zileli M, Ali S. Pharmacologic and regenerative cell therapy for spinal cord injury: WFNS spine committee recommendations. Neurospine. 2020;17(4):785-796. doi:10.14245/ns.2040408.204

17. Sandean D. Management of acute spinal cord injury: a summary of the evidence pertaining to the acute management, operative and nonoperative management. World J Orthop. 2020;11(12):573-583. doi:10.5312/wjo.v11.i12.573

18. Canseco JA, Karamian BA, Bowles DR, et al. Updated review: the steroid controversy for management of spinal cord injury. World Neurosurg 2021;150:1-8. doi:10.1016/j.wneu.2021.02.116

19. Sultan I, Lamba N, Liew A, et al. The safety and efficacy of steroid treatment for acute spinal cord injury: a Systematic Review and metaanalysis. Heliyon. 2020;6(2):e03414. doi:10.1016/j.heliyon.2020.e03414

20. Orr MB, Gensel JC. Spinal cord injury scarring and inflammation: therapies targeting glial and inflammatory responses. Neurotherapeutics. 2018;15(3):541-553. doi:10.1007/s13311-018-0631-6

21. Herbert FJ, Bharathi D, Suresh S, David E, Kumar S. Regenerative potential of Stem cell-derived extracellular vesicles in spinal cord injury (SCI). Curr Stem Cell Res Ther. 2021. doi:10.2174/1574888X16666210923113658

22. Ong WK, Chakraborty S, Sugii S. Adipose tissue: understanding the heterogeneity of stem cells for regenerative medicine. Biomolecules. 2021;11(7):918. doi:10.3390/biom11070918 
23. $\mathrm{Hu} \mathrm{C}, \mathrm{Li} \mathrm{L}$. The immunoregulation of mesenchymal stem cells plays a critical role in improving the prognosis of liver transplantation. $J$ Transl Med. 2019;17(1):412. doi:10.1186/s12967-019-02167-0

24. Iwatani S, Yoshida M, Yamana K, et al. Isolation and characterization of human umbilical cord-derived mesenchymal stem cells from preterm and term infants. J Vis Exp. 2019;143:e58806.

25. Fu Q, Zhang Q, Jia LY, et al. Isolation and characterization of rat mesenchymal stem cells derived from granulocyte colony-stimulating factormobilized peripheral blood. Cells Tissues Organs. 2015;201(6):412-422. doi:10.1159/000445855

26. Tian J, Hong Y, Zhu Q, et al. Mesenchymal stem cell enhances the function of MDSCs in experimental Sjogren syndrome. Front Immunol. 2020;11:604607. doi:10.3389/fimmu.2020.604607

27. Lv X, Wang L, Zou X, Huang S. Umbilical cord mesenchymal stem cell therapy for regenerative treatment of rheumatoid arthritis: opportunities and challenges. Drug Des Devel Ther. 2021;15:3927-3936. doi:10.2147/DDDT.S323107

28. Song EM, Joo YH, Choe AR, et al. Three-dimensional culture method enhances the therapeutic efficacies of tonsil-derived mesenchymal stem cells in murine chronic colitis model. Sci Rep. 2021;11(1):19589. doi:10.1038/s41598-021-98711-4

29. Xiao X, Li W, Rong D, et al. Human umbilical cord mesenchymal stem cells-derived extracellular vesicles facilitate the repair of spinal cord injury via the miR-29b-3p/PTEN/Akt/mTOR axis. Cell Death Discov. 2021;7(1):212. doi:10.1038/s41420-021-00572-3

30. Boido M, Ghibaudi M, Gentile P, Favaro E, Fusaro R, Tonda-Turo C. Chitosan-based hydrogel to support the paracrine activity of mesenchymal stem cells in spinal cord injury treatment. Sci Rep. 2019;9(1):6402. doi:10.1038/s41598-019-42848-w

31. Maldonado-Lasuncion I, Verhaagen J, Oudega M. Mesenchymal stem cell-macrophage choreography supporting spinal cord repair. Neurotherapeutics. 2018;15(3):578-587. doi:10.1007/s13311-018-0629-0

32. Gadani SP, Walsh JT, Lukens JR, Kipnis J. Dealing with danger in the CNS: the response of the immune system to injury. Neuron. 2015;87 (1):47-62. doi:10.1016/j.neuron.2015.05.019

33. Yao C, Cao X, Yu B. Revascularization after traumatic spinal cord injury. Front Physiol. 2021;12:631500. doi:10.3389/fphys.2021.631500

34. Matsushita T, Lankford KL, Arroyo EJ, et al. Diffuse and persistent blood-spinal cord barrier disruption after contusive spinal cord injury rapidly recovers following intravenous infusion of bone marrow mesenchymal stem cells. Exp Neurol. 2015;267:152-164. doi:10.1016/j. expneurol.2015.03.001

35. Xin W, Qiang S, Jianing D, et al. Human bone marrow mesenchymal stem cell-derived exosomes attenuate blood-spinal cord barrier disruption via the TIMP2/MMP pathway after acute spinal cord injury. Mol Neurobiol. 2021;58(12):6490-6504. doi:10.1007/s12035-021-02565-w

36. Al Mamun A, Wu Y, Monalisa I, et al. Role of pyroptosis in spinal cord injury and its therapeutic implications. J Adv Res. 2021;28:97-109. doi:10.1016/j.jare.2020.08.004

37. Fan H, Tang HB, Chen Z, et al. Inhibiting HMGB1-RAGE axis prevents pro-inflammatory macrophages/microglia polarization and affords neuroprotection after spinal cord injury. J Neuroinflammation. 2020;17(1):295. doi:10.1186/s12974-020-01973-4

38. Ji H, Zhang Y, Chen C, et al. D-dopachrome tautomerase activates COX2/PGE2 pathway of astrocytes to mediate inflammation following spinal cord injury. $J$ Neuroinflammation. 2021;18(1):130. doi:10.1186/s12974-021-02186-z

39. Gaudet AD, Fonken LK. Glial cells shape pathology and repair after spinal cord injury. Neurotherapeutics. 2018;15(3):554-577.

40. Takata F, Nakagawa S, Matsumoto J, Dohgu S. Blood-brain barrier dysfunction amplifies the development of neuroinflammation: understanding of cellular events in brain microvascular endothelial cells for prevention and treatment of BBB dysfunction. Front Cell Neurosci. 2021;15:661838. doi:10.3389/fncel.2021.661838

41. Khadka B, Lee JY, Kim KT, Bae JS. Recent progress in therapeutic drug delivery systems for treatment of traumatic CNS injuries. Future Med Chem. 2020;12(19):1759-1778. doi:10.4155/fmc-2020-0178

42. Dolma S, Kumar H. Neutrophil, extracellular matrix components, and their interlinked action in promoting secondary pathogenesis after spinal cord injury. Mol Neurobiol. 2021;58(9):4652-4665. doi:10.1007/s12035-021-02443-5

43. Zivkovic S, Ayazi M, Hammel G, Ren Y. For better or for worse: a look into neutrophils in traumatic spinal cord injury. Front Cell Neurosci. 2021;15:648076. doi:10.3389/fncel.2021.648076

44. Hassanzadeh S, Jalessi M, Jameie SB, et al. More attention on glial cells to have better recovery after spinal cord injury. Biochem Biophys Rep. 2021;25:100905. doi:10.1016/j.bbrep.2020.100905

45. Fleming JC, Norenberg MD, Ramsay DA, et al. The cellular inflammatory response in human spinal cords after injury. Brain. 2006;129(Pt 12):3249-3269. doi:10.1093/brain/awl296

46. Ma SF, Chen YJ, Zhang JX, et al. Adoptive transfer of M2 macrophages promotes locomotor recovery in adult rats after spinal cord injury. Brain Behav Immun. 2015;45:157-170. doi:10.1016/j.bbi.2014.11.007

47. Beck KD, Nguyen HX, Galvan MD, Salazar DL, Woodruff TM, Anderson AJ. Quantitative analysis of cellular inflammation after traumatic spinal cord injury: evidence for a multiphasic inflammatory response in the acute to chronic environment. Brain. 2010;133(2):433-447. doi:10.1093/brain/awp322

48. Anjum A, Yazid MD, Fauzi Daud M, et al. Spinal cord injury: pathophysiology, multimolecular interactions, and underlying recovery mechanisms. Int J Mol Sci. 2020;21(20):7533. doi:10.3390/ijms21207533

49. Garcia E, Aguilar-Cevallos J, Silva-Garcia R, Ibarra A. Cytokine and growth factor activation in vivo and in vitro after spinal cord injury. Mediators Inflamm. 2016;2016:1-21. doi:10.1155/2016/9476020

50. Kiran S, Dwivedi P, Kumar V, Price RL, Singh UP. Immunomodulation and biomaterials: key players to repair volumetric muscle loss. Cells. 2021;10(8):2016. doi:10.3390/cells10082016

51. Gensel JC, Zhang B. Macrophage activation and its role in repair and pathology after spinal cord injury. Brain Res. 2015;1619:1-11. doi:10.1016/j.brainres.2014.12.045

52. Nosbaum A, Prevel N, Truong HA, et al. Cutting edge: regulatory T cells facilitate cutaneous wound healing. J Immunol. 2016;196(5):20102014. doi:10.4049/jimmunol.1502139

53. Deonarine K, Panelli MC, Stashower ME, et al. Gene expression profiling of cutaneous wound healing. J Transl Med. $2007 ; 5(1): 11$. doi:10.1186/1479-5876-5-11

54. Nakazaki M, Morita T, Lankford KL, Askenase PW, Kocsis JD. Small extracellular vesicles released by infused mesenchymal stromal cells target M2 macrophages and promote TGF-beta upregulation, microvascular stabilization and functional recovery in a rodent model of severe spinal cord injury. J Extracell Vesicles. 2021;10(11):e12137. doi:10.1002/jev2.12137 
55. Amo-Aparicio J, Garcia-Garcia J, Puigdomenech M, et al. Inhibition of the NLRP3 inflammasome by OLT1177 induces functional protection and myelin preservation after spinal cord injury. Exp Neurol. 2021;347:113889. doi:10.1016/j.expneurol.2021.113889

56. Chio JCT, Wang J, Surendran V, et al. Delayed administration of high dose human immunoglobulin G enhances recovery after traumatic cervical spinal cord injury by modulation of neuroinflammation and protection of the blood spinal cord barrier. Neurobiol Dis. 2021;148:105187. doi:10.1016/j.nbd.2020.105187

57. Gaire BP, Choi JW. Critical roles of lysophospholipid receptors in activation of neuroglia and their neuroinflammatory responses. Int J Mol Sci. 2021;22(15):7864. doi:10.3390/ijms22157864

58. Francos-Quijorna I, Santos-Nogueira E, Gronert K, et al. Maresin 1 promotes inflammatory resolution, neuroprotection, and functional neurological recovery after spinal cord injury. J Neurosci. 2017;37(48):11731-11743. doi:10.1523/JNEUROSCI.1395-17.2017

59. Fan R, Zhang Y, Botchway BOA, Liu X. Resveratrol can attenuate astrocyte activation to treat spinal cord injury by inhibiting inflammatory responses. Mol Neurobiol. 2021;58(11):5799-5813. doi:10.1007/s12035-021-02509-4

60. Zhang H, Younsi A, Zheng G, et al. Sonic Hedgehog modulates the inflammatory response and improves functional recovery after spinal cord injury in a thoracic contusion-compression model. Eur Spine J. 2021;30(6):1509-1520. doi:10.1007/s00586-021-06796-2

61. Brockie S, Hong J, Fehlings MG. The role of microglia in modulating neuroinflammation after spinal cord injury. Int J Mol Sci. 2021;22 (18):9706. doi:10.3390/ijms22189706

62. Gaojian T, Dingfei Q, Linwei L, et al. Parthenolide promotes the repair of spinal cord injury by modulating M1/M2 polarization via the NF-kB and STAT 1/3 signaling pathway. Cell Death Discovery. 2020;6(1):97. doi:10.1038/s41420-020-00333-8

63. Kigerl KA, Gensel JC, Ankeny DP, Alexander JK, Donnelly DJ, Popovich PG. Identification of two distinct macrophage subsets with divergent effects causing either neurotoxicity or regeneration in the injured mouse spinal cord. $J$ Neurosci. 2009;29(43):13435-13444. doi:10.1523/ JNEUROSCI.3257-09.2009

64. Akhmetzyanova E, Kletenkov K, Mukhamedshina Y, Rizvanov A. Different approaches to modulation of microglia phenotypes after spinal cord injury. Front Syst Neurosci. 2019;13:37. doi:10.3389/fnsys.2019.00037

65. Milich LM, Ryan CB, Lee JK. The origin, fate, and contribution of macrophages to spinal cord injury pathology. Acta Neuropathol. $2019 ; 137$ (5):785-797. doi:10.1007/s00401-019-01992-3

66. Mosser DM, Edwards JP. Exploring the full spectrum of macrophage activation. Nat Rev Immunol. 2008;8(12):958-969. doi:10.1038/nri2448

67. Krausgruber T, Blazek K, Smallie T, et al. IRF5 promotes inflammatory macrophage polarization and TH1-TH17 responses. Nat Immunol. 2011;12(3):231-238. doi:10.1038/ni.1990

68. Guo J, Wang H, Li L, Yuan Y, Shi X, Hou S. Treatment with IL-19 improves locomotor functional recovery after contusion trauma to the spinal cord. Br J Pharmacol. 2018;175(13):2611-2621. doi:10.1111/bph.14193

69. Ghosh M, Xu Y, Pearse DD. Cyclic AMP is a key regulator of M1 to M2a phenotypic conversion of microglia in the presence of Th2 cytokines. J Neuroinflammation. 2016;13(1):9. doi:10.1186/s12974-015-0463-9

70. Li M, Xu J, Mei X, et al. Regulatory effects of dermal papillary pluripotent stem cells on polarization of macrophages from M1 to M2 phenotype in vitro. Transpl Immunol. 2019;52:57-67. doi:10.1016/j.trim.2018.11.003

71. Duan K, Liu S, Yi Z, et al. S100-beta aggravates spinal cord injury via activation of M1 macrophage phenotype. J Musculoskelet Neuronal Interact. 2021;21(3):401-412.

72. Hart CG, Karimi-Abdolrezaee S. Recent insights on astrocyte mechanisms in CNS homeostasis, pathology, and repair. J Neurosci Res. 2021;99 (10):2427-2462. doi:10.1002/jnr.24922

73. Ahmed A, Patil AA, Agrawal DK. Immunobiology of spinal cord injuries and potential therapeutic approaches. Mol Cell Biochem. 2018;441(12):181-189. doi:10.1007/s11010-017-3184-9

74. Mussbacher M, Salzmann M, Brostjan C, et al. Cell type-specific roles of NF-кB linking inflammation and thrombosis. Front Immunol. 2019;10:85. doi:10.3389/fimmu.2019.00085

75. Tang R, Botchway BOA, Meng Y, et al. The inhibition of inflammatory signaling pathway by secretory leukocyte protease inhibitor can improve spinal cord injury. Cell Mol Neurobiol. 2020;40(7):1067-1073. doi:10.1007/s10571-020-00799-1

76. Xu L, Botchway BOA, Zhang S, Zhou J, Liu X. Inhibition of NF-кB signaling pathway by resveratrol improves spinal cord injury. Front Neurosci. 2018;12:690. doi:10.3389/fnins.2018.00690

77. Brambilla R, Bracchi-Ricard V, Hu W-H, et al. Inhibition of astroglial nuclear factor $\mathrm{\kappa B}$ reduces inflammation and improves functional recovery after spinal cord injury. J Exp Med. 2005;202(1):145-156. doi:10.1084/jem.20041918

78. Brambilla R, Hurtado A, Persaud T, et al. Transgenic inhibition of astroglial NF- $\mathrm{KB}$ leads to increased axonal sparing and sprouting following spinal cord injury. J Neurochem. 2009;110(2):765-778. doi:10.1111/j.1471-4159.2009.06190.x

79. Khorooshi R, Babcock AA, Owens T. NF-kB-driven STAT2 and CCL2 expression in astrocytes in response to brain injury. $J$ Immunol. 2008;181(10):7284-7291. doi:10.4049/jimmunol.181.10.7284

80. Yuan J, Liu W, Zhu H, et al. Curcumin inhibits glial scar formation by suppressing astrocyte-induced inflammation and fibrosis in vitro and in vivo. Brain Res. 2017;1655:90-103. doi:10.1016/j.brainres.2016.11.002

81. Anderson MA, Burda JE, Ren Y, et al. Astrocyte scar formation aids central nervous system axon regeneration. Nature. 2016;532(7598):195200. doi:10.1038/nature 17623

82. Zamanian JL, Xu L, Foo LC, et al. Genomic analysis of reactive astrogliosis. J Neurosci. 2012;32(18):6391-6410. doi:10.1523/ JNEUROSCI.6221-11.2012

83. Escartin C, Galea E, Lakatos A, et al. Reactive astrocyte nomenclature, definitions, and future directions. Nat Neurosci. 2021;24(3):312-325. doi:10.1038/s41593-020-00783-4

84. Li X, Li M, Tian L, Chen J, Liu R, Ning B. Reactive astrogliosis: implications in spinal cord injury progression and therapy. Oxid Med Cell Longev. 2020;2020:9494352. doi:10.1155/2020/9494352

85. Zou HJ, Guo SW, Zhu L, Xu X, Liu JB. Methylprednisolone induces neuro-protective effects via the inhibition of A1 astrocyte activation in traumatic spinal cord injury mouse models. Front Neurosci. 2021;15:628917. doi:10.3389/fnins.2021.628917

86. Lana D, Ugolini F, Nosi D, Wenk GL, Giovannini MG. The emerging role of the interplay among astrocytes, microglia, and neurons in the hippocampus in health and disease. Front Aging Neurosci. 2021;13:651973. doi:10.3389/fnagi.2021.651973 
87. Kisucka A, Bimbova K, Bacova M, Galik J, Lukacova N. Activation of neuroprotective microglia and astrocytes at the lesion site and in the adjacent segments is crucial for spontaneous locomotor recovery after spinal cord injury. Cells. 2021;10(8):1943. doi:10.3390/cells10081943

88. Liu LR, Liu JC, Bao JS, Bai QQ, Wang GQ. Interaction of microglia and astrocytes in the neurovascular unit. Front Immunol. $2020 ; 11: 1024$. doi:10.3389/fimmu.2020.01024

89. Liddelow SA, Barres BA. Reactive astrocytes: production, function, and therapeutic potential. Immunity. 2017;46(6):957-967. doi:10.1016/j. immuni.2017.06.006

90. Boghdadi AG, Teo L, Bourne JA. The neuroprotective role of reactive astrocytes after central nervous system injury. J Neurotrauma. 2020;37 (5):681-691. doi:10.1089/neu.2019.6938

91. Xu L, Ye X, Wang Q, et al. T-cell infiltration, contribution and regulation in the central nervous system post-traumatic injury. Cell Prolif. 2021;54(8):e13092. doi:10.1111/cpr.13092

92. Duffy MM, Ritter T, Ceredig R, Griffin MD. Mesenchymal stem cell effects on T-cell effector pathways. Stem Cell Res Ther. $2011 ; 2(4): 34$. doi: $10.1186 /$ scrt75

93. Talaat RM, Mohamed SF, Bassyouni IH, Raouf AA. Th1/Th2/Th17/Treg cytokine imbalance in systemic lupus erythematosus (SLE) patients: correlation with disease activity. Cytokine. 2015;72(2):146-153. doi:10.1016/j.cyto.2014.12.027

94. Monahan R, Stein A, Gibbs K, Bank M, Bloom O. Circulating T cell subsets are altered in individuals with chronic spinal cord injury. Immunol Res. 2015;63(1-3):3-10. doi:10.1007/s12026-015-8698-1

95. Hu JG, Shi LL, Chen YJ, et al. Differential effects of myelin basic protein-activated Th1 and Th2 cells on the local immune microenvironment of injured spinal cord. Exp Neurol. 2016;277:190-201. doi:10.1016/j.expneurol.2016.01.002

96. Chaudhry SR, Kahlert UD, Kinfe TM, et al. Differential polarization and activation dynamics of systemic T helper cell subsets after aneurysmal subarachnoid hemorrhage (SAH) and during post-SAH complications. Sci Rep. 2021;11(1):14226.

97. Szabo SJ, Kim ST, Costa GL, Zhang X, Fathman CG, Glimcher LH. A novel transcription factor, T-bet, directs Th1 lineage commitment. Cell. 2000;100(6):655-669. doi:10.1016/S0092-8674(00)80702-3

98. Butcher MJ, Zhu J. Recent advances in understanding the Th1/Th2 effector choice. Fac Rev. 2021;10:30. doi:10.12703/r/10-30

99. Raphael I, Nalawade S, Eagar TN, Forsthuber TG. T cell subsets and their signature cytokines in autoimmune and inflammatory diseases. Cytokine. 2015;74(1):5-17. doi:10.1016/j.cyto.2014.09.011

100. Rahimi K, Ahmadi A, Hassanzadeh K, et al. Targeting the balance of $\mathrm{T}$ helper cell responses by curcumin in inflammatory and autoimmune states. Autoimmun Rev. 2019;18(7):738-748. doi:10.1016/j.autrev.2019.05.012

101. Hendrix S, Nitsch R. The role of T helper cells in neuroprotection and regeneration. J Neuroimmunol. 2007;184(1-2):100-112. doi:10.1016/j. jneuroim.2006.11.019

102. Qu N, Xu M, Mizoguchi I, et al. Pivotal roles of T-helper 17-related cytokines, IL-17, IL-22, and IL-23, in inflammatory diseases. Clin Dev Immunol. 2013;2013:968549. doi:10.1155/2013/968549

103. Liu D, Liu B, Lin C, Gu J. Imbalance of peripheral lymphocyte subsets in patients with ankylosing spondylitis: a meta-analysis. Front Immunol. 2021;12:696973. doi:10.3389/fimmu.2021.696973

104. Tuzlak S, Dejean AS, Iannacone M, et al. Repositioning TH cell polarization from single cytokines to complex help. Nat Immunol. 2021;22 (10):1210-1217. doi:10.1038/s41590-021-01009-w

105. Carvalheiro T, Rafael-Vidal C, Malvar-Fernandez B, et al. Semaphorin4A-plexin D1 axis induces Th2 and Th17 while represses Th1 skewing in an autocrine manner. Int J Mol Sci. 2020;21(18):6965. doi:10.3390/ijms21186965

106. Lin W, Chen W, Liu W, Xu Z, Zhang L. Sirtuin4 suppresses the anti-neuroinflammatory activity of infiltrating regulatory $\mathrm{T}$ cells in the traumatically injured spinal cord. Immunology. 2019;158(4):362-374. doi:10.1111/imm.13123

107. Sakaguchi S, Miyara M, Costantino CM, Hafler DA. FOXP3+ regulatory T cells in the human immune system. Nat Rev Immunol. 2010;10 (7):490-500. doi:10.1038/nri2785

108. Chen J, Chen YQ, Shi YJ, et al. VX-765 reduces neuroinflammation after spinal cord injury in mice. Neural Regen Res. 2021;16(9):1836-1847. doi:10.4103/1673-5374.306096

109. Zhou Z, Tian X, Mo B, et al. Adipose mesenchymal stem cell transplantation alleviates spinal cord injury-induced neuroinflammation partly by suppressing the Jagged1/Notch pathway. Stem Cell Res Ther. 2020;11(1):212. doi:10.1186/s13287-020-01724-5

110. Urdzíková L, Růžička J, LaBagnara M, et al. Human mesenchymal stem cells modulate inflammatory cytokines after spinal cord injury in rat. Int J Mol Sci. 2014;15(7):11275-11293. doi:10.3390/ijms150711275

111. Tsumuraya T, Ohtaki H, Song D, et al. Human mesenchymal stem/stromal cells suppress spinal inflammation in mice with contribution of pituitary adenylate cyclase-activating polypeptide (PACAP). J Neuroinflammation. 2015;12:35. doi:10.1186/s12974-015-0252-5

112. Nakajima H, Uchida K, Guerrero AR, et al. Transplantation of mesenchymal stem cells promotes an alternative pathway of macrophage activation and functional recovery after spinal cord injury. J Neurotrauma. 2012;29(8):1614-1625. doi:10.1089/neu.2011.2109

113. Maeda Y, Otsuka T, Takeda M, et al. Transplantation of rat cranial bone-derived mesenchymal stem cells promotes functional recovery in rats with spinal cord injury. Sci Rep. 2021;11(1):21907. doi:10.1038/s41598-021-01490-1

114. Bao CS, Li XL, Liu L, Wang B, Yang FB, Chen LG. Transplantation of Human umbilical cord mesenchymal stem cells promotes functional recovery after spinal cord injury by blocking the expression of IL-7. Eur Rev Med Pharmacol Sci. 2018;22(19):6436-6447. doi:10.26355/ eurrev 20181016056

115. Papa S, Vismara I, Mariani A, et al. Mesenchymal stem cells encapsulated into biomimetic hydrogel scaffold gradually release CCL2 chemokine in situ preserving cytoarchitecture and promoting functional recovery in spinal cord injury. $J$ Control Release. 2018;278:49-56. doi:10.1016/j.jconrel.2018.03.034

116. Matsubara K, Matsushita Y, Sakai K, et al. Secreted ectodomain of sialic acid-binding Ig-like lectin-9 and monocyte chemoattractant protein-1 promote recovery after rat spinal cord injury by altering macrophage polarity. J Neurosci. 2015;35(6):2452-2464. doi:10.1523/ JNEUROSCI.4088-14.2015

117. Fu Q, Liu Y, Liu X, et al. Engrafted peripheral blood-derived mesenchymal stem cells promote locomotive recovery in adult rats after spinal cord injury. Am J Transl Res. 2017;9(9):3950-3966.

118. Nitzsche F, Muller C, Lukomska B, Jolkkonen J, Deten A, Boltze J. Concise review: MSC adhesion cascade-insights into homing and transendothelial migration. Stem Cells. 2017;35(6):1446-1460. doi:10.1002/stem.2614 
119. Ferrini E, Stellari FF, Franceschi V, et al. Persistency of mesenchymal stromal/stem cells in lungs. Front Cell Dev Biol. $2021 ; 9: 709225$. doi:10.3389/fcell.2021.709225

120. Markov A, Thangavelu L, Aravindhan S, et al. Mesenchymal stem/stromal cells as a valuable source for the treatment of immune-mediated disorders. Stem Cell Res Ther. 2021;12(1):192. doi:10.1186/s13287-021-02265-1

121. Hassanshahi G, Roohi MA, Esmaeili SA, Pourghadamyari H, Nosratabadi R. Involvement of various chemokine/chemokine receptor axes in trafficking and oriented locomotion of mesenchymal stem cells in multiple sclerosis patients. Cytokine. 2021;148:155706. doi:10.1016/j. cyto.2021.155706

122. Li Q, Lian Y, Deng Y, et al. mRNA-engineered mesenchymal stromal cells expressing CXCR2 enhances cell migration and improves recovery in IBD. Mol Ther Nucleic Acids. 2021;26:222-236. doi:10.1016/j.omtn.2021.07.009

123. Andrzejewska A, Dabrowska S, Lukomska B, Janowski M. Mesenchymal stem cells for neurological disorders. Adv Sci. 2021;8(7):2002944. doi:10.1002/advs.202002944

124. Johnson LDV, Pickard MR, Johnson WEB. The comparative effects of mesenchymal stem cell transplantation therapy for spinal cord injury in humans and animal models: a systematic review and meta-analysis. Biology. 2021;10(3):230. doi:10.3390/biology10030230

125. Lindsay SL, Barnett SC. Therapeutic potential of niche-specific mesenchymal stromal cells for spinal cord injury repair. Cells. 2021;10(4):901. doi:10.3390/cells10040901

126. Silva-Carvalho AE, Cardoso MH, Alencar-Silva T, et al. Dissecting the relationship between antimicrobial peptides and mesenchymal stem cells. Pharmacol Ther. 2021:108021. doi:10.1016/j.pharmthera.2021.108021

127. Miceli V, Bulati M, Iannolo G, Zito G, Gallo A, Conaldi PG. Therapeutic properties of mesenchymal stromal/stem cells: the need of cell priming for cell-free therapies in regenerative medicine. Int J Mol Sci. 2021;22(2):763. doi:10.3390/ijms22020763

128. Lavoie JR, Rosu-Myles M. Uncovering the secretes of mesenchymal stem cells. Biochimie. 2013;95(12):2212-2221. doi:10.1016/j. biochi.2013.06.017

129. Sykova E, Cizkova D, Kubinova S. Mesenchymal stem cells in treatment of spinal cord injury and amyotrophic lateral sclerosis. Front Cell Dev Biol. 2021;9:695900. doi:10.3389/fcell.2021.695900

130. Lv B, Zhang X, Yuan J, et al. Biomaterial-supported MSC transplantation enhances cell-cell communication for spinal cord injury. Stem Cell Res Ther. 2021;12(1):36. doi:10.1186/s13287-020-02090-y

131. Samsonraj RM, Raghunath M, Nurcombe V, Hui JH, van Wijnen AJ, Cool SM. Concise review: multifaceted characterization of human mesenchymal stem cells for use in regenerative medicine. Stem Cells Transl Med. 2017;6(12):2173-2185. doi:10.1002/sctm.170129

132. Antonios JP, Farah GJ, Cleary DR, Martin JR, Ciacci JD, Pham MH. Immunosuppressive mechanisms for stem cell transplant survival in spinal cord injury. Neurosurg Focus. 2019;46(3):E9. doi:10.3171/2018.12.FOCUS18589

133. Chen D, Zeng W, Fu Y, Gao M, Lv G. Bone marrow mesenchymal stem cells combined with minocycline improve spinal cord injury in a rat model. Int J Clin Exp Pathol. 2015;8(10):11957-11969.

134. An N, Yang J, Wang H, et al. Mechanism of mesenchymal stem cells in spinal cord injury repair through macrophage polarization. Cell Biosci. 2021;11(1):41. doi:10.1186/s13578-021-00554-z

135. Yang R, Gao H, Chen L, et al. Effect of peripheral blood-derived mesenchymal stem cells on macrophage polarization and Th17/Treg balance in vitro. Regen Ther. 2020;14:275-283. doi:10.1016/j.reth.2020.03.008

136. Eggenhofer E, Hoogduijn MJ. Mesenchymal stem cell-educated macrophages. Transplant Res. 2012;1(1):12. doi:10.1186/2047-1440-1-12

137. Cho DI, Kim MR, Jeong HY, et al. Mesenchymal stem cells reciprocally regulate the M1/M2 balance in mouse bone marrow-derived macrophages. Exp Mol Med. 2014;46:e70. doi:10.1038/emm.2013.135

138. Selleri S, Bifsha P, Civini S, et al. Human mesenchymal stromal cell-secreted lactate induces M2-macrophage differentiation by metabolic reprogramming. Oncotarget. 2016;7(21):30193-30210. doi:10.18632/oncotarget.8623

139. Takafuji Y, Hori M, Mizuno T, Harada-Shiba M. Humoral factors secreted from adipose tissue-derived mesenchymal stem cells ameliorate atherosclerosis in Ldlr-/- mice. Cardiovasc Res. 2019;115(6):1041-1051. doi:10.1093/cvr/cvy271

140. Sun G, Li G, Li D, et al. hucMSC derived exosomes promote functional recovery in spinal cord injury mice via attenuating inflammation. Mater Sci Eng C Mater Biol Appl. 2018;89:194-204. doi:10.1016/j.msec.2018.04.006

141. Zhai X, Chen K, Yang H, et al. Extracellular vesicles derived from CD73 modified human umbilical cord mesenchymal stem cells ameliorate inflammation after spinal cord injury. $J$ Nanobiotechnology. 2021;19(1):274. doi:10.1186/s12951-021-01022-z

142. Lee JR, Kyung JW, Kumar H, et al. Targeted delivery of mesenchymal stem cell-derived nanovesicles for spinal cord injury treatment. Int J Mol Sci. 2020;21(11):4185. doi:10.3390/ijms21114185

143. Prockop DJ. Concise review: two negative feedback loops place mesenchymal stem/stromal cells at the center of early regulators of inflammation. Stem Cells. 2013;31(10):2042-2046. doi:10.1002/stem.1400

144. Nemeth K, Leelahavanichkul A, Yuen PS, et al. Bone marrow stromal cells attenuate sepsis via prostaglandin E(2)-dependent reprogramming of host macrophages to increase their interleukin-10 production. Nat Med. 2009;15(1):42-49. doi:10.1038/nm.1905

145. Francois M, Romieu-Mourez R, Li M, Galipeau J. Human MSC suppression correlates with cytokine induction of indoleamine 2,3-dioxygenase and bystander M2 macrophage differentiation. Mol Ther. 2012;20(1):187-195. doi:10.1038/mt.2011.189

146. Song X, Xie S, Lu K, Wang C. Mesenchymal stem cells alleviate experimental asthma by inducing polarization of alveolar macrophages. Inflammation. 2015;38(2):485-492. doi:10.1007/s10753-014-9954-6

147. Braza F, Dirou S, Forest V, et al. Mesenchymal stem cells induce suppressive macrophages through phagocytosis in a mouse model of asthma. Stem Cells. 2016;34(7):1836-1845. doi:10.1002/stem.2344

148. Melief SM, Geutskens SB, Fibbe WE, Roelofs H. Multipotent stromal cells skew monocytes towards an anti-inflammatory interleukin-10producing phenotype by production of interleukin-6. Haematologica. 2013;98(6):888-895. doi:10.3324/haematol.2012.078055

149. Freytes DO, Kang JW, Marcos-Campos I, Vunjak-Novakovic G. Macrophages modulate the viability and growth of human mesenchymal stem cells. $J$ Cell Biochem. 2013;114(1):220-229. doi:10.1002/jcb.24357

150. Maldonado-Lasuncion I, Haggerty AE, Okuda A, et al. The effect of inflammatory priming on the therapeutic potential of mesenchymal stromal cells for spinal cord repair. Cells. 2021;10(6):1316. doi:10.3390/cells10061316 
151. Chen L, Zhang Q, Chen QH, et al. Combination of G-CSF and AMD3100 improves the anti-inflammatory effect of mesenchymal stem cells on inducing M2 polarization of macrophages through NF-kappaB-IL1RA signaling pathway. Front Pharmacol. 2019;10:579. doi:10.3389/ fphar.2019.00579

152. Choi H, Lee RH, Bazhanov N, Oh JY, Prockop DJ. Anti-inflammatory protein TSG-6 secreted by activated MSCs attenuates zymosan-induced mouse peritonitis by decreasing TLR2/NF-kappaB signaling in resident macrophages. Blood. 2011;118(2):330-338. doi:10.1182/blood-2010$12-327353$

153. Sica A, Mantovani A. Macrophage plasticity and polarization: in vivo veritas. J Clin Invest. 2012;122(3):787-795. doi:10.1172/JCI59643

154. Ip WKE, Hoshi N, Shouval DS, Snapper S, Medzhitov R. Anti-inflammatory effect of IL-10 mediated by metabolic reprogramming of macrophages. Science. 2017;356(6337):513-519. doi:10.1126/science.aal3535

155. Ouyang W, Rutz S, Crellin NK, Valdez PA, Hymowitz SG. Regulation and functions of the IL-10 family of cytokines in inflammation and disease. Anпи Rev Immunol. 2011;29:71-109. doi:10.1146/annurev-immunol-031210-101312

156. Qian D, Li L, Rong Y, et al. Blocking Notch signal pathway suppresses the activation of neurotoxic A1 astrocytes after spinal cord injury. Cell Cycle. 2019;18(21):3010-3029. doi:10.1080/15384101.2019.1667189

157. Liddelow SA, Guttenplan KA, Clarke LE, et al. Neurotoxic reactive astrocytes are induced by activated microglia. Nature. 2017;541 (7638):481-487. doi:10.1038/nature21029

158. Jiang D, Gong F, Ge X, et al. Neuron-derived exosomes-transmitted miR-124-3p protect traumatically injured spinal cord by suppressing the activation of neurotoxic microglia and astrocytes. J Nanobiotechnology. 2020;18(1):105. doi:10.1186/s12951-020-00665-8

159. Schäfer S, Calas A-G, Vergouts M, Hermans E. Immunomodulatory influence of bone marrow-derived mesenchymal stem cells on neuroinflammation in astrocyte cultures. J Neuroimmunol. 2012;249(1-2):40-48. doi:10.1016/j.jneuroim.2012.04.018

160. Wang S, Jia Y, Cao X, et al. HUCMSCs transplantation combined with ultrashort wave therapy attenuates neuroinflammation in spinal cord injury through NUR77/ NF-kappaB pathway. Life Sci. 2021;267:118958. doi:10.1016/j.lfs.2020.118958

161. Wang L, Pei S, Han L, et al. Mesenchymal stem cell-derived exosomes reduce A1 astrocytes via downregulation of phosphorylated NFkappaB P65 subunit in spinal cord injury. Cell Physiol Biochem. 2018;50(4):1535-1559. doi:10.1159/000494652

162. Ceyzeriat K, Abjean L, Carrillo-de Sauvage MA, Ben Haim L, Escartin C. The complex STATes of astrocyte reactivity: how are they controlled by the JAK-STAT3 pathway? Neuroscience. 2016;330:205-218. doi:10.1016/j.neuroscience.2016.05.043

163. Gu Y, He M, Zhou X, et al. Endogenous IL-6 of mesenchymal stem cell improves behavioral outcome of hypoxic-ischemic brain damage neonatal rats by suppressing apoptosis in astrocyte. Sci Rep. 2016;6:18587. doi:10.1038/srep18587

164. Norden DM, Fenn AM, Dugan A, Godbout JP. TGFbeta produced by IL-10 redirected astrocytes attenuates microglial activation. Glia. 2014;62 (6):881-895. doi:10.1002/glia.22647

165. Luo K. Signaling cross talk between TGF-beta/Smad and other signaling pathways. Cold Spring Harb Perspect Biol. $2017 ; 9(1)$ :a022137. doi:10.1101/cshperspect.a022137

166. Liu R, Wang W, Wang S, Xie W, Li H, Ning B. microRNA-21 regulates astrocytic reaction post-acute phase of spinal cord injury through modulating TGF-beta signaling. Aging. 2018;10(6):1474-1488. doi:10.18632/aging.101484

167. Li T, Liu T, Chen X, et al. Microglia induce the transformation of A1/A2 reactive astrocytes via the CXCR7/PI3K/Akt pathway in chronic postsurgical pain. J Neuroinflammation. 2020;17(1):211. doi:10.1186/s12974-020-01891-5

168. Liu F, Qiu H, Xue M, et al. MSC-secreted TGF- $\beta$ regulates lipopolysaccharide-stimulated macrophage M2-like polarization via the Akt/FoxO1 pathway. Stem Cell Res Ther. 2019;10(1):345. doi:10.1186/s13287-019-1447-y

169. Li X, Dong Y, Yin H, Qi Z, Wang D, Ren S. Mesenchymal stem cells induced regulatory dendritic cells from hemopoietic progenitor cells through Notch pathway and TGF-beta synergistically. Immunol Lett. 2020;222:49-57. doi:10.1016/j.imlet.2020.03.005

170. Luz-Crawford P, Kurte M, Bravo-Alegria J, et al. Mesenchymal stem cells generate a CD4+CD25+Foxp3+ regulatory T cell population during the differentiation process of Th1 and Th17 cells. Stem Cell Res Ther. 2013;4(3):65. doi:10.1186/scrt216

171. Weiss ARR, Dahlke MH. Immunomodulation by mesenchymal stem cells (MSCs): mechanisms of action of living, apoptotic, and dead MSCs. Front Immunol. 2019;10:1191. doi:10.3389/fimmu.2019.01191

172. Mokarizadeh A, Delirezh N, Morshedi A, Mosayebi G, Farshid AA, Mardani K. Microvesicles derived from mesenchymal stem cells: potent organelles for induction of tolerogenic signaling. Immunol Lett. 2012;147(1-2):47-54. doi:10.1016/j.imlet.2012.06.001

173. Zhang B, Yin Y, Lai RC, Tan SS, Choo AB, Lim SK. Mesenchymal stem cells secrete immunologically active exosomes. Stem Cells Dev. 2014;23(11):1233-1244. doi:10.1089/scd.2013.0479

174. Meisel R, Zibert A, Laryea M, Gobel U, Daubener W, Dilloo D. Human bone marrow stromal cells inhibit allogeneic T-cell responses by indoleamine 2,3-dioxygenase-mediated tryptophan degradation. Blood. 2004;103(12):4619-4621. doi:10.1182/blood-2003-11-3909

175. Wang Y, Chen X, Cao W, Shi Y. Plasticity of mesenchymal stem cells in immunomodulation: pathological and therapeutic implications. Nat Immunol. 2014;15(11):1009-1016. doi:10.1038/ni.3002

176. Sato K, Ozaki K, Oh I, et al. Nitric oxide plays a critical role in suppression of T-cell proliferation by mesenchymal stem cells. Blood. 2007;109 (1):228-234. doi:10.1182/blood-2006-02-002246

177. Bouffi C, Bony C, Courties G, Jorgensen C, Noel D. IL-6-dependent PGE2 secretion by mesenchymal stem cells inhibits local inflammation in experimental arthritis. PLoS One. 2010;5(12):e14247. doi:10.1371/journal.pone.0014247

178. Matysiak M, Orlowski W, Fortak-Michalska M, Jurewicz A, Selmaj K. Immunoregulatory function of bone marrow mesenchymal stem cells in EAE depends on their differentiation state and secretion of PGE2. J Neuroimmunol. 2011;233(1-2):106-111. doi:10.1016/j. jneuroim.2010.12.004

179. Selmani Z, Naji A, Zidi I, et al. Human leukocyte antigen-G5 secretion by human mesenchymal stem cells is required to suppress T lymphocyte and natural killer function and to induce CD4+CD25highFOXP3+ regulatory T cells. Stem Cells. 2008;26(1):212-222. doi:10.1634/stemcells.2007-0554

180. Wang K, Shi YJ, Song ZL, et al. Regulatory effect of rat bone marrow mesenchymal stem cells on Treg/Th17 immune balance in vitro. Mol Med Rep. 2020;21(5):2123-2130. doi:10.3892/mmr.2020.11019

181. Melief SM, Schrama E, Brugman MH, et al. Multipotent stromal cells induce human regulatory T cells through a novel pathway involving skewing of monocytes toward anti-inflammatory macrophages. Stem Cells. 2013;31(9):1980-1991. doi:10.1002/stem.1432 
182. Lee HJ, Kim SN, Jeon MS, Yi T, Song SU. ICOSL expression in human bone marrow-derived mesenchymal stem cells promotes induction of regulatory T cells. Sci Rep. 2017;7:44486. doi:10.1038/srep44486

183. Martinez AM, Goulart CO, Ramalho Bdos S, Oliveira JT, Almeida FM. Neurotrauma and mesenchymal stem cells treatment: from experimental studies to clinical trials. World J Stem Cells. 2014;6(2):179-194. doi:10.4252/wjsc.v6.i2.179

184. Zhilai Z, Biling M, Sujun Q, et al. Preconditioning in lowered oxygen enhances the therapeutic potential of human umbilical mesenchymal stem cells in a rat model of spinal cord injury. Brain Res. 2016;1642:426-435. doi:10.1016/j.brainres.2016.04.025

185. Mammana S, Gugliandolo A, Cavalli E, et al. Human gingival mesenchymal stem cells pretreated with vesicular moringin nanostructures as a new therapeutic approach in a mouse model of spinal cord injury. J Tissue Eng Regen Med. 2019;13(7):1109-1121. doi:10.1002/term.2857

186. Wang W, Huang X, Lin W, et al. Hypoxic preconditioned bone mesenchymal stem cells ameliorate spinal cord injury in rats via improved survival and migration. Int $J$ Mol Med. 2018;42(5):2538-2550. doi:10.3892/ijmm.2018.3810

187. Noori L, Arabzadeh S, Mohamadi Y, et al. Intrathecal administration of the extracellular vesicles derived from human Wharton's jelly stem cells inhibit inflammation and attenuate the activity of inflammasome complexes after spinal cord injury in rats. Neurosci Res. 2021;170:87-98. doi:10.1016/j.neures.2020.07.011

188. Liu W, Rong Y, Wang J, et al. Exosome-shuttled miR-216a-5p from hypoxic preconditioned mesenchymal stem cells repair traumatic spinal cord injury by shifting microglial M1/M2 polarization. $J$ Neuroinflammation. 2020;17(1):47. doi:10.1186/s12974-020-1726-7

189. Lankford KL, Arroyo EJ, Nazimek K, Bryniarski K, Askenase PW, Kocsis JD. Intravenously delivered mesenchymal stem cell-derived exosomes target M2-type macrophages in the injured spinal cord. PLoS One. 2018;13(1):e0190358. doi:10.1371/journal.pone.0190358

190. Fan L, Dong J, He X, Zhang C, Zhang T. Bone marrow mesenchymal stem cells-derived exosomes reduce apoptosis and inflammatory response during spinal cord injury by inhibiting the TLR4/MyD88/NF-kB signaling pathway. Hum Exp Toxicol. 2021;40(10):1612-1623. doi:10.1177/ 09603271211003311

191. Shang AJ, Hong SQ, Xu Q, et al. NT-3-secreting human umbilical cord mesenchymal stromal cell transplantation for the treatment of acute spinal cord injury in rats. Brain Res. 2011;1391:102-113. doi:10.1016/j.brainres.2011.03.019

192. Li G, Che MT, Zeng X, et al. Neurotrophin-3 released from implant of tissue-engineered fibroin scaffolds inhibits inflammation, enhances nerve fiber regeneration, and improves motor function in canine spinal cord injury. J Biomed Mater Res A. 2018;106(8):2158-2170. doi:10.1002/jbm. a. 36414

193. Allahdadi KJ, De santana TA, Santos GC, et al. IGF-1 overexpression improves mesenchymal stem cell survival and promotes neurological recovery after spinal cord injury. Stem Cell Res Ther. 2019;10(1):146. doi:10.1186/s13287-019-1223-z

194. Liu W, Wang Y, Gong F, et al. Exosomes derived from bone mesenchymal stem cells repair traumatic spinal cord injury by suppressing the activation of A1 neurotoxic reactive astrocytes. J Neurotrauma. 2019;36(3):469-484. doi:10.1089/neu.2018.5835

195. Li Z, Wang Q, Hu H, Zheng W, Gao C. Research advances of biomaterials-based microenvironment-regulation therapies for repair and regeneration of spinal cord injury. Biomed Mater. 2021;16(5):052002. doi:10.1088/1748-605X/ac1d3c

196. Ha XQ, Yang B, Hou HJ, Cai XL, Xiong WY, Wei XP. Protective effect of rhodioloside and bone marrow mesenchymal stem cells infected with HIF-1-expressing adenovirus on acute spinal cord injury. Neural Regen Res. 2020;15(4):690-696. doi:10.4103/1673-5374.266920

197. Amiri F, Jahanian-Najafabadi A, Roudkenar MH. In vitro augmentation of mesenchymal stem cells viability in stressful microenvironments: in vitro augmentation of mesenchymal stem cells viability. Cell Stress Chaperones. 2015;20(2):237-251. doi:10.1007/s12192-014-0560-1

198. Yang Y, Lee EH, Yang Z. Hypoxia conditioned mesenchymal stem cells in tissue regeneration application. Tissue Eng Part B Rev. 2021. doi:10.1089/ten.TEB.2021.0145

199. Philipp D, Suhr L, Wahlers T, Choi YH, Paunel-Gorgulu A. Preconditioning of bone marrow-derived mesenchymal stem cells highly strengthens their potential to promote IL-6-dependent M2b polarization. Stem Cell Res Ther. 2018;9(1):286. doi:10.1186/s13287-018-1039-2

200. Collison LW, Workman CJ, Kuo TT, et al. The inhibitory cytokine IL-35 contributes to regulatory T-cell function. Nature. 2007;450(7169):566569. doi:10.1038/nature 06306

201. Guo H, Zhao N, Gao H, He X. Mesenchymal stem cells overexpressing interleukin-35 propagate immunosuppressive effects in mice. Scand $J$ Immunol. 2017;86(5):389-395. doi:10.1111/sji.12613

202. Dooley D, Lemmens E, Vangansewinkel T, et al. Cell-based delivery of interleukin-13 directs alternative activation of macrophages resulting in improved functional outcome after spinal cord injury. Stem Cell Reports. 2016;7(6):1099-1115. doi:10.1016/j.stemcr.2016.11.005

Journal of Inflammation Research

Dovepress

\section{Publish your work in this journal}

The Journal of Inflammation Research is an international, peer-reviewed open-access journal that welcomes laboratory and clinical findings on the molecular basis, cell biology and pharmacology of inflammation including original research, reviews, symposium reports, hypothesis formation and commentaries on: acute/chronic inflammation; mediators of inflammation; cellular processes; molecular mechanisms; pharmacology and novel anti-inflammatory drugs; clinical conditions involving inflammation. The manuscript management system is completely online and includes a very quick and fair peer-review system. Visit http://www.dovepress.com/testimonials.php to read real quotes from published authors.

Submit your manuscript here: https://www.dovepress.com/journal-of-inflammation-research-journal 